\title{
Melatonin-Induced Water Stress Tolerance in Plants: Recent Advances
}

\author{
Mohamed Moustafa-Farag ${ }^{1,2, *,+}$, Ahmed Mahmoud ${ }^{2,3,+}{ }^{\mathbb{C}}$, Marino B. Arnao ${ }^{4}(\mathbb{D}$, \\ Mohamed S. Sheteiwy ${ }^{5}$, Mohamed Dafea ${ }^{2}{ }^{10}$, Mahmoud Soltan ${ }^{6,7}$, Amr Elkelish ${ }^{8}(\mathbb{0}$, \\ Mirza Hasanuzzaman ${ }^{9}$ and Shaoying $\mathrm{Ai}^{1, *}$ \\ 1 Institute of Agricultural Resources and Environment, Guangdong Academy of Agricultural Sciences, \\ Guangzhou 510640, China \\ 2 Horticulture Research Institute, Agriculture Research Center, 9 Gmaa St, Giza 12619, Egypt; \\ 11716103@zju.edu.cn (A.M.); mohameddafea@yahoo.com (M.D.) \\ 3 Laboratory of Germplasm Innovation and Molecular Breeding, Institute of Vegetable Science, \\ Zhejiang University, Hangzhou 310058, China \\ 4 Department of Plant Physiology, Faculty of Biology, University of Murcia, 30100 Murcia, Spain; \\ marino@um.es \\ 5 Department of Agronomy, Faculty of Agriculture, Mansoura University, Mansoura 35516, Egypt; \\ salahco_2010@mans.edu.eg \\ 6 Horticulture and Crop Science Department, Ohio Agricultural Research and Development Center, \\ Columbus, The Ohio State University, Columbus, OH 43210, USA; dsoltan2012@gmail.com \\ 7 Vegetable Production under Modified Environment Department, Horticulture Research Institute, \\ Agriculture Research Center, Cairo 11865, Egypt \\ 8 Botany Department, Faculty of Science, Suez Canal University, Ismailia 41522, Egypt; \\ amr.elkelish@science.suez.edu.eg \\ 9 Department of Agronomy, Faculty of Agriculture, Sher-e-Bangla Agricultural University, Dhaka 1207, \\ Bangladesh; mhzsauag@yahoo.com \\ * Correspondence: m_m_kamel2005@gdaas.cn (M.M.-F.); aishaoying@gdaas.cn (S.A.); \\ Tel.: +86-020-3288-5970 (S.A.) \\ + These authors contributed equally to this work.
}

Received: 1 July 2020; Accepted: 18 August 2020; Published: 1 September 2020

\begin{abstract}
Water stress (drought and waterlogging) is severe abiotic stress to plant growth and development. Melatonin, a bioactive plant hormone, has been widely tested in drought situations in diverse plant species, while few studies on the role of melatonin in waterlogging stress conditions have been published. In the current review, we analyze the biostimulatory functions of melatonin on plants under both drought and waterlogging stresses. Melatonin controls the levels of reactive oxygen and nitrogen species and positively changes the molecular defense to improve plant tolerance against water stress. Moreover, the crosstalk of melatonin and other phytohormones is a key element of plant survival under drought stress, while this relationship needs further investigation under waterlogging stress. In this review, we draw the complete story of water stress on both sides-drought and waterlogging - through discussing the previous critical studies under both conditions. Moreover, we suggest several research directions, especially for waterlogging, which remains a big and vague piece of the melatonin and water stress puzzle.
\end{abstract}

Keywords: melatonin; water stress; drought; waterlogging; abiotic stress; antioxidants; stress signaling; phytohormones 


\section{Introduction}

With the notable increase in global warming, rainfall disparity, and poor drainage, water stress (drought and waterlogging) is becoming one of the fiercest environmental challenges in the agriculture sector, mainly in the arid and semiarid regions for drought stress [1,2], and in the areas of heavy rainfall, inadequate draining, and flooding for waterlogging stress [3], which could seriously threaten food security by 2050, whenthe world's population is predicted to reach ten billion [4]. The key impact of water stress is the massive generation of reactive oxygen species (ROS) and malondialdehyde (MDA) over the cell tolerance ability [5], therefore, directly and/or indirectly damaging the cell membrane, nucleic acids, and proteins (Figure 1). This adversely affects gas exchange and photosynthesis and decreases plant growth, as well as yield quality and quantity [6-8]. Practically, a global-scale analysis of published studies over the last four decades on maize and wheat revealed that $20-40 \%$ of yield reductions were due to water scarcity [9].Meanwhile, the destructive effect of waterlogging on crop yield has been estimated at a $40-80 \%$ loss in an area of more than 1.7 billion hectares [10-12].

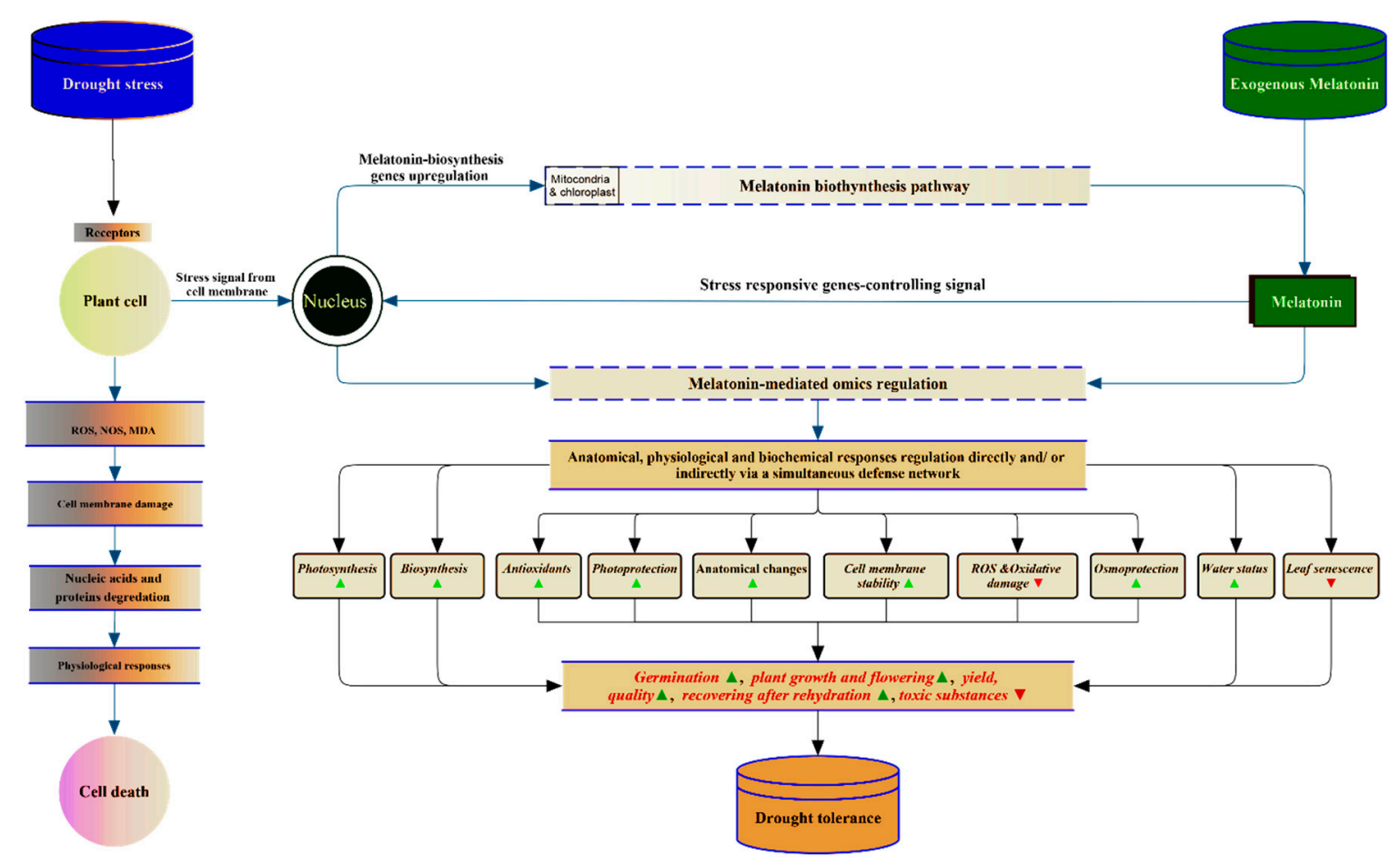

Figure 1. A schematic model explaining the mechanism underlying the melatonin-mediated drought stress response. At the cellular level, a stress signal from the cell membrane is received by the nucleus, which starts to activate the melatonin biosynthesis pathway from its precursor, tryptophan, in mitochondria and chloroplasts by upregulating the melatonin-biosynthesis genes. Melatonin sends its feedback on such stress to the nucleus to activate omics regulation. Consequently, the genes encoding the proteins related to plant anatomical, physiological, and biochemical responses are regulated directly and/or indirectly via a simultaneous defense network. The omics-mediated responses include photosynthesis, biosynthesis, enzymatic and nonenzymatic antioxidants, photoprotection, cell membrane stability, ROS and oxidative damage, osmoprotection, water status, and leaf senescence, in addition to the anatomical changes, which lead to drought tolerance. Consequently, the whole plant status is enhanced, including growth and development, flowering, yield, quality, and survival rate, while the toxic substances are decreased.

Indeed, plants have developed several strategies to cope with water stress. In drought, plants avoid the drastic effects of stress through the induction of stomatal closure, accumulation of compatible solutes, and biosynthesis of wax [4]. Moreover, plants increase their tolerance by the activation 
of antioxidative abilities and the induction of some molecular chaperones to alleviate oxidative damage $[8,13]$. In waterlogging, plants avert stress by altering plant metabolism toward anaerobic, glycolytic, and fermentative metabolism. In response to anoxia, the plant activates the antioxidant machinery, expression of heat shock transcript, and accumulation of osmolytes [14]. Previous publications have stated that the various plant responses to water stress are mediated by essential regulators such as phytohormones [15]. Among them, melatonin is a unique antioxidant and plant master regulator that protects plants from oxidative stress and regulates various plant responses to environmental disorders, especially water stress [16-18]. Although accumulating reviews about the beneficial effects of melatonin have been published over the last decade, it still needs more discussion in order to update and discover melatonin functions, especially under biotic and abiotic stresses [19-21]. Herein, we will discuss the most recent and relevant studies of the protective roles of melatonin-induced water stress tolerance, including anatomical changes, and physiological and molecular mechanisms, as well as its central role in the hormonal system. Moreover, we will address the potential triple relationship, melatonin-nitric oxide-hydrogen sulfide, an emerging research point, in the light of previous water stress research. A grasp of the current situation and consideration of the future perspectives of the roles of melatonin in water stress tolerance will also be deeply discussed.

\section{Melatonin-Induced Drought Stress Tolerance}

\subsection{An Overview}

Among plant growth substances, melatonin (N-acetyl-5-methoxytryptamine) is an amazing and powerful naturally occurring antioxidant that effectively copes with the drastic effects of water deficit in plants $[16,22]$. Thus, melatonin is strongly recommended to mitigate drought stress in several plant species, including model plants [23,24], field crops [25,26], fruit crops [27,28], vegetable crops [29,30], as well as ornamental and medicinal plants $[31,32]$ (Table 1$)$. Melatonin treatment ranges from a very low concentration $(50 \mathrm{nM})$ in grape [33] to a high dosage $(1 \mathrm{mM})$ in maize [34] (Table 1). Moreover, melatonin can be applied in different forms to alleviate drought stress, including seed priming [35], seed coating [36], direct soil treatment [37], foliar application [32], in nutrient solutions and hydroponic systems [38], supplemented with irrigation [27], and roots pretreatment [39] (Table 1). 
Table 1. Roles of melatonin in drought stress tolerance.

\begin{tabular}{|c|c|c|c|c|c|c|}
\hline \multirow{2}{*}{ Common Name } & \multirow{2}{*}{ Scientific Name } & \multirow{2}{*}{ Drought Treatment } & \multicolumn{2}{|c|}{ Melatonin Treatment } & \multirow{2}{*}{ Effects } & \multirow{2}{*}{ Reference } \\
\hline & & & Concentration * & Application Form & & \\
\hline \multicolumn{7}{|c|}{ Model Plants } \\
\hline Arabidopsis & Arabidopsis thaliana & Water withholding (21 d) & $50 \mu \mathrm{M}$ & $\begin{array}{l}\text { Supplemented with } \\
\text { nutrient solution }\end{array}$ & $\begin{array}{c}\text { Stress-responsive genes } \boldsymbol{\Lambda} \text {, soluble } \\
\text { sugars } \boldsymbol{\Delta}\end{array}$ & [40] \\
\hline \multicolumn{7}{|c|}{ Field Crops } \\
\hline Rice & Oryza sativa & $\begin{array}{l}\text { Water drainage from } \\
\text { vessels }(5 \mathrm{~d})\end{array}$ & $100 \mu \mathrm{M}$ & $\begin{array}{l}\text { Pretreatment in } \\
\text { growing distilled } \\
\text { water }\end{array}$ & $\begin{array}{c}\text { Plant growth } \mathbf{\Lambda} \text {, osmoprotectants } \\
\text { proline } \mathbf{\Lambda} \text {, stress-responsive genes } \mathbf{\Lambda}, \\
\text { mitochondrial structure } \mathbf{\Lambda}, \operatorname{ROS} \mathbf{\nabla}, \\
\text { electroleakage } \mathbf{\nabla}\end{array}$ & [41] \\
\hline Maize & Zea mays & $\begin{array}{l}\text { Water withholding }(8 \mathrm{~d}) \text {, } \\
\text { melatonin application } \\
\text { during recovery, followed } \\
\text { by withholding }(8 \mathrm{~d}) .\end{array}$ & $1 \mathrm{mM}$ & $\begin{array}{l}\text { Supplemented with } \\
\text { irrigation }\end{array}$ & Photoprotection (PSII efficiency) $\Delta$ & [34] \\
\hline Maize & Z. mays & $30-60 \%$ SWC (8d) & $100 \mu \mathrm{M}$ & Foliar application & $\begin{array}{c}\text { Recovering after rehydration } \mathbf{\Lambda}, \\
\text { photosynthesis } \mathbf{\Lambda} \text {, stomatal } \\
\text { conductance } \mathbf{\Lambda} \text {, transpiration rates } \mathbf{\Lambda}, \\
\text { cell turgor and water holding } \\
\text { capacity } \mathbf{\Lambda} \text {, enzymatic and } \\
\text { nonenzymatic antioxidants } \mathbf{\Lambda} \\
\text { osmotic potential } \mathbf{\nabla}, \text { ROS } \mathbf{\nabla}\end{array}$ & [42] \\
\hline Maize & Z. mays & $20 \%$ PEG6000(3 d) & $10-100 \mu \mathrm{M}$ & $\begin{array}{l}\text { Foliar application } \\
\text { pre-treatment }\end{array}$ & $\begin{array}{c}\text { Photosynthesis } \mathbf{\Lambda} \text {, antioxidant } \\
\text { enzymes } \mathbf{\Lambda} \text {, carbon fixation } \mathbf{\Lambda} \text {, amino } \\
\text { acids and secondary metabolites } \\
\text { biosynthesis } \mathbf{\Lambda}, \text { ROS } \boldsymbol{\nabla}\end{array}$ & [26] \\
\hline Maize & Z. mays & Water withholding $(7 \mathrm{~d})$ & $100 \mu \mathrm{M}$ & $\begin{array}{c}\text { Two methods } \\
\text { (root-irrigation and } \\
\text { foliar application) }\end{array}$ & Photosynthesis $\Lambda$, ROS $\mathbf{v}$ & [43] \\
\hline Maize & Z. mays & $40-45 \%$ field capacity ( $50 \mathrm{~d}$ ) & $\begin{array}{c}50 \mu \mathrm{M} \text { (foliar spray) } \\
\text { and } 100 \mu \mathrm{M} \text { (soil } \\
\text { drench) }\end{array}$ & $\begin{array}{l}\text { Foliar application or } \\
\text { soil treatment }\end{array}$ & $\begin{array}{c}\text { Photosynthesis } \mathbf{\Lambda} \text {, antioxidant } \\
\text { enzymes } \mathbf{\Lambda} \text {, ROS } \mathbf{v}\end{array}$ & [44] \\
\hline
\end{tabular}


Table 1. Cont.

\begin{tabular}{|c|c|c|c|c|c|c|}
\hline \multirow{2}{*}{ Common Name } & \multirow{2}{*}{ Scientific Name } & \multirow{2}{*}{ Drought Treatment } & \multicolumn{2}{|c|}{ Melatonin Treatment } & \multirow{2}{*}{ Effects } & \multirow{2}{*}{ Reference } \\
\hline & & & Concentration * & Application Form & & \\
\hline Wheat & Triticum aestivum & $\begin{array}{c}40 \% \text { and } 60 \% \text { field capacity } \\
(7 \mathrm{~d})\end{array}$ & $500 \mu \mathrm{M}$ & Soil application & $\begin{array}{c}\text { Chloroplast structure } \mathbf{\Lambda} \\
\text { photosynthesis } \mathbf{\Lambda}, \text { cell turgor and } \\
\text { water holding capacity } \mathbf{\Lambda} \text {, GSH and } \\
\text { AsA contents } \mathbf{\Lambda} \text {, antioxidant } \\
\text { enzymes } \mathbf{\Lambda}, \text { GSH-AsA cycle-related } \\
\text { genes } \mathbf{\Lambda}, \text { ROS } \mathbf{\nabla}, \text { membrane damage }\end{array}$ & [45] \\
\hline Wheat & T. aestivum & $\begin{array}{l}30 \% \text { pot holding capacity } \\
\qquad(8 \mathrm{~d})\end{array}$ & $100 \mu \mathrm{M}$ & Soil application & $\begin{array}{c}\text { Recovering after rehydration } \mathbf{\Lambda}, \\
\text { biomass and root/shoot ratio } \mathbf{\Delta} \\
\text { water holding capacity } \mathbf{\Lambda} \\
\text { chlorophyll } \mathbf{\Lambda} \text {, photosynthesis } \mathbf{\Lambda} \\
\operatorname{ROS} \mathbf{\nabla}, \text { MDA } \mathbf{\nabla}\end{array}$ & [46] \\
\hline Wheat & T. aestivum & 20\% PEG 6000 (7 d) & $\begin{array}{c}10 \text { and } 100 \mu \mathrm{M} \\
\text { (variety-dependent) }\end{array}$ & Seeds treatment & $\begin{array}{c}\text { Germination percentage } \mathbf{\Lambda}, \\
\text { germination index } \mathbf{\Lambda} \text {, germination } \\
\text { potential } \mathbf{\Lambda} \text {, radicle length and } \\
\text { number } \mathbf{\Lambda} \text {, plumule length } \mathbf{\Lambda} \text {, lysine } \\
\text { (germination-related amino acid) } \mathbf{\Delta}\end{array}$ & [47] \\
\hline $\begin{array}{c}\text { Tartary } \\
\text { Buckwheat }\end{array}$ & Fagopyrum tataricum & $20 \%$ field capacity $(15 \mathrm{~d})$ & $100 \mu \mathrm{M}$ & Foliar application & $\begin{array}{c}\text { Water status } \mathbf{\Lambda}, \text { osmoprotection } \mathbf{\Lambda} \\
\text { secondary metabolites } \mathbf{\Lambda} \text {, antioxidant } \\
\text { enzymes } \mathbf{\Lambda} \text {, photosynthesis } \mathbf{\Lambda}, \operatorname{ROS} \mathbf{\nabla}\end{array}$ & [48] \\
\hline Barley & Hordeum vulgare & $\begin{array}{l}\text { (Combined drought and } \\
\text { cold) }\end{array}$ & $1 \mathrm{mM}$ & $\begin{array}{l}\text { Foliar or soil } \\
\text { application }\end{array}$ & $\begin{array}{c}\text { Endogenous melatonin } \mathbf{\Lambda}, \text { ABA } \mathbf{\Lambda}, \\
\text { water status } \mathbf{\Lambda} \text {, antioxidants } \mathbf{\Lambda}, \\
\text { photosynthesis } \mathbf{\Lambda} \text {, PSII efficiency } \mathbf{\Delta}\end{array}$ & [49] \\
\hline Soybean & Glycine max & $20 \%$ field capacity $(10 \mathrm{~d})$ & $50 \mu \mathrm{M}$ & Seed coating & $\begin{array}{c}\text { Seedlings growth } \mathbf{\Lambda} \text {, biomass } \mathbf{\Lambda}, \\
\text { electrolyte leakage } \mathbf{\nabla}\end{array}$ & [36] \\
\hline Soybean & G. $\max$ & 15\% PEG 6000 (7 d) & $100 \mu \mathrm{M}$ & $\begin{array}{l}\text { Supplemented with } \\
\text { nutrient solution }\end{array}$ & Seedlings growth $\mathbf{\Lambda}$, photosynthesis & [38] \\
\hline Soybean & G. $\max$ & $45 \% \operatorname{RSWC}(15 \mathrm{~d})$ & $100 \mu \mathrm{M}$ & Foliar application & $\begin{array}{c}\text { Antioxidant enzymes } \mathbf{\Lambda} \text {, osmolytes } \\
\mathbf{\Lambda}, \text { MDA } \mathbf{\nabla}\end{array}$ & [25] \\
\hline Soybean & G. $\max$ & $15 \%$ PEG6000 (3 d) & $100 \mu \mathrm{M}$ & $\begin{array}{l}\text { Foliar and root } \\
\text { application }\end{array}$ & $\begin{array}{c}\text { Plant growth and flowering } \mathbf{\Lambda} \text {, seed } \\
\text { yield } \mathbf{\Lambda} \text {, gas exchange } \mathbf{\Lambda} \text {, PSII } \\
\text { efficiency } \mathbf{\Lambda} \text {, antioxidant enzymes } \mathbf{\Lambda} \\
\text { MDA } \boldsymbol{\nabla}\end{array}$ & [50] \\
\hline
\end{tabular}


Table 1. Cont.

\begin{tabular}{|c|c|c|c|c|c|c|}
\hline \multirow{2}{*}{ Common Name } & \multirow{2}{*}{ Scientific Name } & \multirow{2}{*}{ Drought Treatment } & \multicolumn{2}{|c|}{ Melatonin Treatment } & \multirow{2}{*}{ Effects } & \multirow{2}{*}{ Reference } \\
\hline & & & Concentration * & Application Form & & \\
\hline Cassava & Manihot esculenta & 20\% PEG $6000(11 \mathrm{~d})$ & $100 \mu \mathrm{M}$ & Soil application & POD activity $\mathbf{\Lambda}$, ROS $\mathbf{\nabla}$ & [37] \\
\hline Cotton & Gossypium hirsutum & 10\% PEG $6000(7 \mathrm{~d})$ & $100 \mu \mathrm{M}$ & Seeds pre-soaking & $\begin{array}{c}\text { Number and opening of stomata in } \\
\text { cotton testa } \mathbf{\Lambda} \text {, germination } \\
\text { parameters } \mathbf{\Lambda} \text {, antioxidant enzymes } \mathbf{\Lambda}, \\
\text { osmoprotection } \mathbf{\Lambda}, \text { GA3 } \mathbf{\Lambda}, \mathrm{ABA} \mathbf{\nabla}, \\
\text { ROS } \mathbf{v}, \text { MDA } \mathbf{\nabla}\end{array}$ & [51] \\
\hline Alfalfa & Medicago sativa & Water withholding (7 d) & $10 \mu \mathrm{M}$ & Soil application & $\begin{array}{c}\text { Chlorophyll } \mathbf{\Lambda} \text {, stomatal conductance } \\
\mathbf{\Lambda} \text {, osmoprotection } \mathbf{\Lambda} \text {, Nitro-oxidative } \\
\text { homeostasis } \mathbf{\Lambda} \text {, cellular redox } \\
\text { disruption } \mathbf{\nabla}, \mathrm{MDA} \mathbf{\nabla}, \mathrm{ROS} \mathbf{\nabla}\end{array}$ & [52] \\
\hline \multicolumn{7}{|c|}{ Fruits } \\
\hline Apple & Malus spp. & Water withholding $(6 \mathrm{~d})$ & $100 \mu \mathrm{M}$ & Soil application & $\begin{array}{c}\text { Water holding capacity } \mathbf{\Lambda}, \\
\text { chlorophyll } \mathbf{\Lambda} \text {, photosynthesis } \mathbf{\Lambda}, \\
\text { antioxidants } \mathbf{\Lambda} \text {, stomatal opening } \\
\text { regulation } \mathbf{\Lambda} \text {, melatonin biosynthesis } \\
\text { genes } \mathbf{\Lambda}, \text { electrolyte leakage } \mathbf{\nabla}, \text { ROS } \\
\mathbf{\nabla}, \text { ABA } \mathbf{v} \text { through ABA synthesis } \\
\text { gene } \mathbf{v} \text { and catabolic genes } \mathbf{\Delta}\end{array}$ & [53] \\
\hline Apple & M. domestica & $\begin{array}{c}50 \% \text { field capacity } \\
(3 \text { months with sampling } \\
\text { every month) }\end{array}$ & $100 \mu \mathrm{M}$ & Soil application & $\begin{array}{c}\text { Plant growth } \mathbf{\Lambda} \text {, nutrients uptake } \\
\text { fluxes } \mathbf{\Lambda}, \text { metabolism } \mathbf{\Lambda}, \\
\text { endogenous melatonin } \mathbf{\Lambda} \\
\text { chlorophyll } \mathbf{\Lambda} \text {, photosynthesis } \mathbf{\Lambda}, \\
\text { relative water content } \mathbf{\Lambda}, \text { stomatal } \\
\text { status } \mathbf{\Lambda} \text {, electrolyte leakage } \mathbf{\nabla}, \text { ROS } \mathbf{\nabla}\end{array}$ & [54] \\
\hline Apple & M. domestica & $\begin{array}{c}50 \% \text { field capacity } \\
\text { (3 months with sampling } \\
\text { every month) }\end{array}$ & $100 \mu \mathrm{M}$ & Soil application & $\begin{array}{c}\text { Chlorophyll } \mathbf{\Lambda} \text {, photosynthesis } \mathbf{\Lambda}, \\
\text { photoprotection } \mathbf{\Lambda} \text {, antioxidant } \\
\text { enzymes } \mathbf{\Lambda} \text {, GSH and AsA contents } \\
\mathbf{\Lambda} \text {, oxidative damage } \mathbf{\nabla} \text {, leaf } \\
\text { senescence } \mathbf{\nabla} \text {, senescence-associated } \\
\text { gene } 12 \boldsymbol{\nabla} \text {, pheophorbide a } \\
\text { oxygenase-related gene } \mathbf{\nabla}, \text { ROS } \mathbf{\nabla}\end{array}$ & [55] \\
\hline
\end{tabular}


Table 1. Cont.

\begin{tabular}{|c|c|c|c|c|c|c|}
\hline \multirow{2}{*}{ Common Name } & \multirow{2}{*}{ Scientific Name } & \multirow{2}{*}{ Drought Treatment } & \multicolumn{2}{|c|}{ Melatonin Treatment } & \multirow{2}{*}{ Effects } & \multirow{2}{*}{ Reference } \\
\hline & & & Concentration * & Application Form & & \\
\hline Grape & Vitis vinifer & 10\% PEG $6000(12 \mathrm{~d})$ & 50,100 and $200 \mathrm{nM}$ & Roots pretreatment & $\begin{array}{c}\text { Photoprotection } \mathbf{\Lambda} \text {, leaf thickness } \mathbf{\Lambda}, \\
\text { spongy tissue } \mathbf{\Lambda} \text {, stoma size } \mathbf{\Lambda}, \\
\text { chloroplast structure } \mathbf{\Lambda} \text {, enzymatic } \\
\text { and nonenzymatic antioxidants } \mathbf{\Lambda}, \\
\text { osmoprotectants (free proline) } \mathbf{\Lambda}, \\
\text { ultrastructural damage } \mathbf{\nabla}, \text { oxidative } \\
\text { injury } \mathbf{\nabla}\end{array}$ & [33] \\
\hline Grapevine & $\begin{array}{l}\text { V. amurensis } V \text {. vinifera } \\
\text { and V. labruscana }\end{array}$ & 10\% PEG $6000(4 \mathrm{~d})$ & $\begin{array}{c}\text { Endophyte } \\
\text { colonization of } \\
\text { secreted-melatonin } \\
\text { bacteria }\end{array}$ & $\begin{array}{l}\text { Bacillus } \\
\text { amyloliquefaciens SB-9 } \\
\text { colonization }\end{array}$ & $\begin{array}{l}\text { Melatonin synthesis and its } \\
\text { intermediates } \mathbf{\Lambda} \text {, plant growth } \mathbf{\Lambda} \\
\text { ROS } \mathbf{v}, \text { MDA } \mathbf{v}\end{array}$ & [56] \\
\hline Grape & V. vinifer & Water withholding (18 d) & $100 \mu \mathrm{M}$ & $\begin{array}{l}\text { Supplemented with } \\
\text { irrigation }\end{array}$ & MDA $\boldsymbol{\nabla}$, relative conductivity $\boldsymbol{\nabla}$ & [57] \\
\hline Grape & V. vinifer & Water withholding (18 d) & $100 \mu \mathrm{M}$ & $\begin{array}{l}\text { Supplemented with } \\
\text { irrigation }\end{array}$ & Chlorophyll $\mathbf{\Lambda}$, SOD activity $\boldsymbol{\Lambda}$ & [28] \\
\hline Kiwifruit & $\begin{array}{c}\text { Actinidia. chinensis var. } \\
\text { deliciosa }\end{array}$ & $\begin{array}{l}\text { Water withholding }(9 \mathrm{~d}) \\
\text { (RWC below } 35 \% \text { field } \\
\text { capacity) }\end{array}$ & $100 \mu \mathrm{M}$ & $\begin{array}{l}\text { Supplemented with } \\
\text { irrigation }\end{array}$ & $\begin{array}{c}\text { Root vigor } \mathbf{\Lambda}, \text { osmoprotectants } \mathbf{\Lambda}, \\
\text { proteins biosynthesis } \mathbf{\Lambda}, \\
\text { chlorophyll } \mathbf{\Lambda} \text {, photosynthesis } \mathbf{\Lambda}, \\
\text { light energy absorption } \mathbf{\Lambda}, \\
\text { photoprotection } \mathbf{\Lambda}, \mathrm{CO}_{2} \\
\text { fixation-associated genes } \mathbf{\Lambda}, \text { MDA } \mathbf{\nabla}, \\
\text { cell membranes damage } \mathbf{v}, \text { stomatal } \\
\text { closure } \mathbf{\nabla}\end{array}$ & [58] \\
\hline Kiwifruit & A. chinesis & water withholding (9 days) & $100 \mu \mathrm{M}$ & $\begin{array}{l}\text { Irrigation } \\
\text { pretreatment }\end{array}$ & $\begin{array}{c}\text { Water holding capacity } \mathbf{\Lambda}, \\
\text { antioxidant enzymes-related genes } \mathbf{\Lambda} \\
\text { GSH-AsA cycle-related genes } \mathbf{\Lambda} \\
\text { ROS } \mathbf{\nabla}, \text { MDA } \mathbf{\nabla}\end{array}$ & [27] \\
\hline Chinese hickory & Carya cathayensis & $30 \%$ PEG $6000(10-40 \mathrm{~d})$ & $100 \mu \mathrm{M}$ & $\begin{array}{l}\text { Foliar application } \\
\text { pretreatment }\end{array}$ & $\begin{array}{c}\text { Recovering after rehydration } \mathbf{\Lambda}, \\
\text { photosynthesis } \mathbf{\Lambda} \text {, antioxidants } \mathbf{\Lambda}, \\
\text { osmoprotectants } \mathbf{\Lambda} \text {, metabolic } \\
\text { pathways-related genes } \mathbf{\Lambda}, \\
\text { antioxidant enzymes-related genes } \mathbf{\Lambda} \\
\text { ROS } \mathbf{\nabla}\end{array}$ & [59] \\
\hline
\end{tabular}


Table 1. Cont.

\begin{tabular}{|c|c|c|c|c|c|c|}
\hline \multirow{2}{*}{ Common Name } & \multirow{2}{*}{ Scientific Name } & \multirow{2}{*}{ Drought Treatment } & \multicolumn{2}{|c|}{ Melatonin Treatment } & \multirow{2}{*}{ Effects } & \multirow{2}{*}{ Reference } \\
\hline & & & Concentration * & Application Form & & \\
\hline \multicolumn{7}{|c|}{ Vegetables } \\
\hline Tomato & Solanum lycopersicum & $\begin{array}{l}\text { Water withholding for } \\
\text { (5-20 d after moderate } \\
\text { drought) }\end{array}$ & $0.1 \mathrm{mM}$ & $\begin{array}{l}\text { Supplemented with } \\
\text { irrigation }\end{array}$ & $\begin{array}{c}\text { Photosynthesis } \mathbf{\Lambda} \text {, root vigor } \mathbf{\Lambda}, \text { PSII } \\
\text { efficiency } \mathbf{\Lambda} \text {, antioxidants } \mathbf{\Lambda} \text {, toxic } \\
\text { substances } \mathbf{v}\end{array}$ & [60] \\
\hline Tomato & S. lycopersicum & $10 \%$ PEG $(7 \mathrm{~d})$ & $200 \mu \mathrm{M}$ & Foliar application & $\begin{array}{c}\text { Chlorophyll } \mathbf{\Lambda}, \text { p-coumaric acid } \\
\text { content } \mathbf{\Lambda} \text {, antioxidant enzymes } \mathbf{\Lambda} \\
\text { MDA } \mathbf{~}\end{array}$ & [29] \\
\hline Pepper & Capsicum anпuum & $10 \%$ PEG $(8 \mathrm{~d})$ & $50 \mu \mathrm{M}$ & Seed pretreatment & $\begin{array}{c}\text { Water holding capacity } \mathbf{\Lambda}, \\
\text { endogenous melatonin } \mathbf{\Lambda}, \text { GSH } \\
\text { content } \mathbf{\Lambda} \text {, chlorophyll } \mathbf{\Lambda} \text {, carotenoids } \\
\mathbf{\Lambda} \text {, proline } \mathbf{\Lambda} \text {, antioxidant enzymes } \mathbf{\Lambda}, \\
\text { MDA } \mathbf{}\end{array}$ & [30] \\
\hline Watermelon & Citrullus lanatus & Water withholding (4 d) & $150 \mu \mathrm{M}$ & Root pretreatment & $\begin{array}{c}\text { Wax accumulation } \mathbf{\Lambda}, \\
\text { melatonin-ABA crosstalk } \mathbf{\Delta}\end{array}$ & [39] \\
\hline Cucumber & Cucumis sativus & 18\% PEG 6000 (days) & $100 \mu \mathrm{M}$ & $\begin{array}{l}\text { Seeds priming and } \\
\text { nutrient solution }\end{array}$ & $\begin{array}{c}\text { Seed germination } \mathbf{\Lambda} \text {, root growth } \mathbf{\Lambda}, \\
\text { root/shoot ratio } \mathbf{\Lambda} \text {, roots vigor } \mathbf{\Lambda}, \\
\text { chlorophyll } \mathbf{\Lambda} \text {, photosynthesis } \mathbf{\Lambda}, \\
\text { chloroplasts ultrastructure } \mathbf{\Lambda}, \\
\text { antioxidant enzymes } \mathbf{\Lambda}, \text { ROS } \mathbf{v}\end{array}$ & [61] \\
\hline Rapeseed & Brassica napus & 4\% PEG $6000(7 \mathrm{~d})$ & $0.05 \mathrm{mM}$ & In PEG solution & $\begin{array}{l}\text { Plant growth } \mathbf{\Lambda} \text {, antioxidants } \mathbf{\Lambda} \\
\text { osmoprotectants } \mathbf{\Lambda}, \text { ROS } \mathbf{v}\end{array}$ & [62] \\
\hline Rapeseed & B. napus & $\begin{array}{c}-0.3 \text { and }-0.4 \mathrm{Mpa} \text { PEG } \\
6000(7 \mathrm{~d})\end{array}$ & $500 \mu \mathrm{M}$ & Seed priming & $\begin{array}{c}\text { Chlorophyll } \mathbf{\Lambda} \text {, stomatal regulation } \\
\mathbf{\Lambda} \text {, chloroplast structure } \mathbf{\Lambda} \text {, cell } \\
\text { expansion and cell wall } \mathbf{\Lambda} \\
\text { antioxidant enzymes } \mathbf{\Lambda} \\
\text { osmoprotectants } \mathbf{\Lambda} \text {, oxidative } \\
\text { injury } \mathbf{\nabla}\end{array}$ & [35] \\
\hline \multicolumn{7}{|c|}{ Ornamental and Medicinal Plants } \\
\hline Jinyu Chuju & $\begin{array}{l}\text { Dendranthma } \\
\text { morifolium }\end{array}$ & $40 \%$ field capacity $(6 \mathrm{~d})$ & $100 \mu \mathrm{M}$ & Foliar application & $\begin{array}{c}\text { Chlorophyll } \mathbf{\Lambda} \text {, photosynthesis } \mathbf{\Lambda} \\
\text { biomass } \mathbf{\Lambda} \text {, osmoprotectants (TSS } \\
\text { and proline) } \mathbf{\Lambda} \text {, cell membrane } \\
\text { damage } \mathbf{\nabla} \text {, relative conductivity } \mathbf{\nabla} \\
\text { MDA } \mathbf{\nabla}\end{array}$ & [63] \\
\hline
\end{tabular}


Table 1. Cont.

\begin{tabular}{|c|c|c|c|c|c|c|}
\hline \multirow{2}{*}{ Common Name } & \multirow{2}{*}{ Scientific Name } & \multirow{2}{*}{ Drought Treatment } & \multicolumn{2}{|c|}{ Melatonin Treatment } & \multirow{2}{*}{ Effects } & \multirow{2}{*}{ Reference } \\
\hline & & & Concentration * & Application Form & & \\
\hline $\begin{array}{l}\text { Moldavian balm } \\
\text { (Dragon head) }\end{array}$ & $\begin{array}{l}\text { Dracocephalum } \\
\text { moldavica }\end{array}$ & $40-60 \%$ field capacity & $100 \mu \mathrm{M}$ & Foliar application & $\begin{array}{c}\text { Plant growth and flowering } \mathbf{\Lambda} \\
\text { antioxidants } \mathbf{\Lambda} \text {, chlorophyll } \mathbf{\Lambda} \text {, water } \\
\text { holding capacity } \mathbf{\Lambda}, \operatorname{ROS} \mathbf{\nabla}, \text { MDA } \boldsymbol{\nabla}\end{array}$ & [64] \\
\hline $\begin{array}{l}\text { Creeping } \\
\text { bentgrass }\end{array}$ & Agrostisstolonifera & Water withholding $(14 \mathrm{~d})$ & $20 \mu \mathrm{M}$ & Foliar application & $\begin{array}{c}\text { Visual quality } \mathbf{\Lambda} \text {, PSII efficiency } \mathbf{\Lambda} \text {, } \\
\text { chlorophyll } \mathbf{\Lambda} \text {, water holding } \\
\text { capacity } \mathbf{\Lambda} \text {, melatonin biosynthesis } \\
\text { genes } \mathbf{\Lambda} \text {, dehydration responsive } \\
\text { genes } \mathbf{\Lambda} \text {, Chlorophyll-degradation } \\
\text { genes } \mathbf{\nabla} \text {, leaf senescence } \mathbf{\nabla} \text {, ROS } \mathbf{\nabla} \text {, } \\
\text { MDA } \mathbf{\nabla}\end{array}$ & [65] \\
\hline Tall fescue & Festuca arundinacea & Water withholding $(10 \mathrm{~d})$ & $20 \mu \mathrm{M}$ & $\begin{array}{l}\text { Irrigation } \\
\text { pretreatment }\end{array}$ & $\begin{array}{c}\text { Plant growth } \mathbf{\Lambda} \text {, chlorophyll } \mathbf{\Lambda}, \\
\text { antioxidant enzymes } \mathbf{\Lambda}, \text { ROS } \mathbf{v}, \\
\text { MDA } \mathbf{v}\end{array}$ & [66] \\
\hline Bermudagrass & Cynodon dactylon & Withholding water (21 d) & 20 and $100 \mu \mathrm{M}$ & $\begin{array}{l}\text { Irrigation } \\
\text { pretreatment }\end{array}$ & $\begin{array}{c}\text { Plant growth } \mathbf{\Lambda} \text {, chlorophyll } \mathbf{\Lambda}, \\
\text { survival rate } \mathbf{\Lambda} \text {, antioxidant enzymes } \\
\mathbf{\Lambda} \text {, stress-responsive genes } \mathbf{\Lambda} \\
\text { metabolic regulation } \mathbf{\Lambda} \text {, hormonal } \\
\text { signaling-related genes regulation } \mathbf{\Lambda}, \\
\text { ROS } \mathbf{\nabla}\end{array}$ & [67] \\
\hline Fenugreek & $\begin{array}{c}\text { Trigonella } \\
\text { foenum-graecum }\end{array}$ & 19.5\% PEG 6000(21 d) & 100 and $300 \mu \mathrm{M}$ & $\begin{array}{l}\text { Foliar application } \\
\text { pre-treatment }\end{array}$ & $\begin{array}{c}\text { Endogenous melatonin and } \\
\text { secondary metabolites } \mathbf{\Lambda} \text {, chlorophyll } \\
\mathbf{\Lambda} \text {, antioxidant enzymes } \mathbf{\Lambda}, \text { ROS } \mathbf{}\end{array}$ & [68] \\
\hline Coffee & Coffea arabica & $\begin{array}{l}40 \% \text { of max moisture } \\
\text { retention capacity }(21 \mathrm{~d})\end{array}$ & $300 \mu \mathrm{M}$ & Soil application & $\begin{array}{c}\text { Root vigor } \mathbf{\Lambda} \text {, photoprotection } \mathbf{\Lambda} \text {, gas } \\
\text { exchange } \mathbf{\Lambda} \text {, carboxylation efficiency } \\
\mathbf{\Lambda} \text {, chlorophyll } \mathbf{\Lambda} \text {, antioxidants } \mathbf{\Lambda} \\
\text { MDA } \mathbf{v}\end{array}$ & [31] \\
\hline Tea & Camellia sinensis & 20\% PEG 6000 (2 d) & $100 \mu \mathrm{M}$ & $\begin{array}{l}\text { Foliar application } \\
\text { pre-treatment }\end{array}$ & $\begin{array}{c}\text { Photosynthesis } \mathbf{\Lambda}, \mathrm{GSH} \text { and AsA } \\
\text { contents } \mathbf{\Lambda} \text {, antioxidant enzymes } \mathbf{\Lambda} \\
\text { antioxidant enzymes-related genes } \\
\mathbf{\Lambda}, \operatorname{ROS} \mathbf{\nabla}, \text { MDA } \mathbf{\nabla}\end{array}$ & [32] \\
\hline \multicolumn{7}{|c|}{ Other Crops } \\
\hline $\begin{array}{l}\text { Tobacco, Tomato } \\
\text { and Cucumber }\end{array}$ & $\begin{array}{l}\text { Nicotiana benthamiana, } \\
\text { S. lycopersicum and C. } \\
\text { sativus }\end{array}$ & Water withholding (6 d) & $10 \mu \mathrm{M}$ & Foliar application & MDA $\mathbf{\nabla}$, drought tolerance $\boldsymbol{\Lambda}$ & [23] \\
\hline
\end{tabular}

$\mathbf{\Delta}$ or $\mathbf{v}$, enhanced or decreased compared to control. ROS, reactive oxygen species; PSII, photosystem II; GSH, glutathione; AsA, ascorbate; MDA, malondialdehyde; ABA, abscisic acid; GA3, gibberellic acid; SOD, superoxide dismutase; POD, peroxidase; TSS, total soluble sugar. ${ }^{*}$ Only those doses of exogenous melatonin that had a superior positive impact on plant tolerance against drought stress have been selected. 


\subsection{Melatonin is Involved in Drought Stress Tolerance}

Given the wide use of melatonin in drought stress alleviation, it has been of interest for the scientific community to investigate the direct evidence of melatonin involvement in drought tolerance. This takes place through melatonin biosynthesis genes such as tryptophan decarboxylase (TDC), $\mathrm{N}$-acetylserotonin methyltransferase $(A S M T)$, serotonin $\mathrm{N}$-acetyltransferase (SNAT), and caffeic acid O-methyltransferase (COMT). In this respect, the endogenous melatonin levels change with the alteration of the environmental conditions of plant growth. The melatonin level is increased, with a protective role, in response to different abiotic stressors such as cold, heat, heavy metals, UV radiation, water deficit, and waterlogging [18,22]. Thus, the expressions of the biosynthesis enzyme transcripts (TDC, SNAT, ASMT, and COMT genes) occur in stressful situations, producing a burst in the levels of endogenous melatonin. The global influence of environmental factors on the melatonin levels of plant organs was demonstrated in barley, tomato, and lupin plants by Arnao and coworkers [69-71]. Some representative examples of melatonin induction by drought can be consulted in studies on Arabidopsis [24], barley [49], bermudagrass [67], apple [53], grapevine [56], and rice [72]. In these cases, an increase in the melatonin level, between 2- and 6-fold, in one or more transcripts of melatonin biosynthesis enzymes due to stress conditions have been described [72,73].

\subsection{Mechanisms of Melatonin-Induced Drought Stress Tolerance}

\subsubsection{Anatomical Changes and Physiological Mechanisms}

In the last few years, the role of melatonin as a multifunctional regulator of plant status under drought conditions, including (i) anatomical and (ii) physiological aspects, have been progressively studied and, notably, reached more than 42 studies within seven years (Table 1). (i) The anatomical changes are induced by melatonin within the different plant organs, including less cell membrane damage [63], more intact grana lamella of the chloroplast [45], alleviation of chloroplast ultrastructural damage and preservation of its system [33,61], safeguarding of the mitochondrial structure [67], maintenance of cell expansion [35], better leaf thickness, spongy tissue, and stomata size [33,35], cuticle formation [74], and wax accumulation [39]. (ii) By increasing drought severity, melatonin, which is biosynthesized in mitochondria and chloroplasts [75,76], exhibits more defense strategies. It promotes the physiological aspects, including the antioxidant system [27,59], to alleviate the oxidative damage, leading to less accumulation of reactive oxygen and nitrogen species (ROS and RNS) $[25,52]$, less electrolyte leakage [41], lower lipid peroxidation (malondialdehyde reduction) [27,65], lower relative conductivity [57], the easing of toxic substances content [60], cellular redox disruption limitation [52], better nitro-oxidative homeostasis [52], and enhanced ascorbate (AsA)-glutathione(GSH) cycle capacity (higher GSH and AsA contents) [54]. Such beneficial effects are carried out by regulating enzymatic activity involving peroxidase (POD), ascorbate peroxidase (APX), catalase (CAT), and superoxide dismutase (SOD), as well as nonenzymatic antioxidants and osmoprotectants (proline and others) $[37,44,64]$, and also secondary metabolites such as flavonoids, phenolics, and phenylalanine ammonialyase [48]. Simultaneously, melatonin improves the plant photosystem, as indicated by higher chlorophyll content [58], greater photosynthetic rates [43], and higher transpiration rates [31]. Moreover, melatonin has been proven to enhance photoprotection via improving photosystem II efficiency [34]. As a multifunctional substance, melatonin also regulates the osmotic potential of the cell [42] via the accumulation of soluble sugars and proline [62]. Moreover, water status is one of the most important priorities of melatonin to control under drought conditions. In this respect, melatonin enhances plant resistance via higher stomatal conductance [42], higher cell turgor and water holding capacity [65], and stomatal opening regulation [77]. Consequently, the whole plant status is enhanced, including seed germination efficiency [47], root generation vitality and strength [61], growth and flowering [36,50], visual quality [65], seed yield [38], leaf senescence alleviation [54], and quick recovery after rehydration [59]. 


\subsubsection{Molecular Mechanisms}

\section{Omics of Redox Hemostasis and Plant Built-In Processes}

The protective mechanisms of melatonin have also been studied, and the ability of melatonin to protect plant cells against redox homeostasis disruption in response to drought stress has been focused on. Melatonin regulates ROS/reactive nitrogen species (ROS/RNS) levels and antioxidant-related genes, including SOD, POD, CAT, APX, glutathione S-transferase (GSTP), monodehydroascorbate reductase (MDHAR), dehydroascorbate reductase (DHAR), and glutathione reductase $(G R)[27,30,32,37,43,45,52,56,59,78]$, as well as osmoprotective elements via the regulation of proline biosynthesis genes [52]. Melatonin not only alleviates oxidative damage, but also regulates plant built-in-associated genes, including carbohydrate/fatty and amino acids metabolism [26,36,37], the carbon metabolic pathway [67], nitrogen metabolism and transport [37,54], plant secondary metabolism [59], energy production [37,78], carotenoid metabolism and photosynthesis [27,36,37,59], and cuticle wax biosynthesis [74]. In this regard, the metabolism of carbohydrate/fatty acids has been reported to be upregulated via the seed-coating of soybean with a melatonin solution as a means to improve its tolerance to drought stress [36]. Melatonin is also a key regulator of nitrogen (N) metabolism and transport, as indicated by the higher expression levels of $\mathrm{N}$ uptake genes $(A M T 2-1$, AMT1-2, AMT1-6, AMT1-5, NRT1-1, NRT2-5, NRT2, and 7NRT2-4) and metabolic genes (NADH-GOGAT $N R, F d-G O G A T, N i R$, and GS) in the leaves of apple trees [54].

Omics of Energy Production, Photosynthesis, and Wax Biosynthesis

Melatonin promotes energy production under water scarcity through regulating glycolytic protein expression and electron transport in the respiratory chain [78]. Moreover, melatonin governs the photosynthesis process via the regulation of molecular elements involved in the enzymatic activities of carbon dioxide $\left(\mathrm{CO}_{2}\right)$ fixation (PGK, TKT, FBA, RPI, FBP, GAPA, TIM, RPK, Rubisco, SEBP, and $R P E$ ) [58], protein expression for carbon fixation [26], light reaction of photosynthesis (cytochrome P450) [37], and tetrapyrrole pigment biosynthesis [37,56,65]. Photosynthesis has also been reported to be upregulated via the seed-coating of soybean with a melatonin solution as a means to improve its tolerance to drought and salinity stress [36]. Among the interesting genes upregulated by melatonin, there are two subunits of photosystem I (PS I; PsaG and PsaK) and two elements (PsbO and PsbP) related to the oxygen-evolving complex of PS II (oxygen-evolving enhancer proteins) [36]. Moreover, melatonin upregulates the relative expression of the PetF ferredoxin gene(which controls the amount of reduced ascorbate and protects chlorophyll from degradation) and the VTC4 gene, encoding the L-galactose 1-P-phosphatase for ascorbate biosynthesis [36]. In another study, Ma et al. [65] reported that melatonin inhibited the gene expression and enzyme activities of chlorophyll-degradation genes, including chlase, Chl-PRX, and PPH, in melatonin-treated plants during drought stress, which directly affects photosynthesis performance. On the other hand, Ding et al., [74] tested the relative expression of four wax biosynthesis-related genes, including KCS1(responsible for fatty acid elongation), CER3(involved in alkane synthesis), TTS1(associated with triterpenoids synthesis), and LTP1(accountable for lipids transport). It was remarked that the transcripts of the four genes were triggered by drought stress and were further induced as a result of melatonin treatment, demonstrating the role of melatonin in enhancing wax biosynthesis [74].

\section{Omics of Stomatal Movement, Autophagy, and Others}

Melatonin-mediated stomatal closure mechanism has also been investigated, suggesting that melatonin is a phytohormone that triggers stomatal closure via the signaling pathway ofPMTR1, which controls hydrogen peroxide $\left(\mathrm{H}_{2} \mathrm{O}_{2}\right)$ production and the $\mathrm{Ca}^{2+}$ signalingtransduction cascade [77]. PMTR1 is a phytomelatonin receptor that has a receptor-like topology and interacts with the subunit of G-protein A (GPA1) in the plasma membrane [77]. The phytomelatonin-receptor binding drives the dissociation of $\mathrm{G} \gamma \beta$ and $\mathrm{G} \alpha$ (heterotrimeric G-proteins), which triggers NADPH oxidase-dependent 
$\mathrm{H}_{2} \mathrm{O}_{2}$ release and activates $\mathrm{Ca}^{2+}$ as well as $\mathrm{K}^{+}$efflux, leading to stomatal closure [77]. In addition, NAPDH oxidase, as a respiratory burst oxidase, generates superoxide radicals, which then undergoes dismutation to hydrogen peroxide either enzymatic or nonenzymatically. Under excessive drought, plants resort to getting rid of dysfunctional or unnecessary cellular components in order to facilitate the orderly degradation and recycling of cellular components through the autophagy mechanism. The regulatory role of melatonin in autophagy is elucidated in wheat seedlings via the enhancement of the metabolic process associated with autophagy, represented by the upregulation of the fused signal recognition particle receptor, Rab-related protein, serine protease, and aspartyl protease at the protein or mRNA level [78]. Moreover, melatonin regulates the action of key transcription factors such as Myb4, $A P 37$, and zinc finger $[41,67]$ in parallel with some transporter proteins, including proton transporter (UCP1), potassium transporter (HKT1), and water channel protein (PIP2;1) [41], which are all essential elements in stress tolerance. Moreover, melatonin application orchestrates some stress-signaling genes such as calcium and protein kinases-related genes, implying that kinase signaling could prove to have essential roles in drought tolerance [67].

All in all, as shown in Figure 1, it can be concluded that once the plants feel water scarcity under drought conditions, the protective and regulatory role of melatonin, in parallel with other anti-stress strategies, will start to prevent, alleviate, or stop the harmful effects of the stress $[18,79]$. At the cellular level, stress signals from the cell membrane inform the nucleus that "cell life is under threat" to cope with the drastic effects of the drought $[77,80]$. Quickly, the nucleus starts to activate the melatonin biosynthesis pathway from its precursor, tryptophan, in mitochondria and chloroplasts $[75,76,81]$ through the upregulation of the melatonin-biosynthesis genes [53,65]. Remarkably, melatonin starts by sending its feedback on such stress to the nucleus to trigger the appropriate stress response through omics regulation $[40,45,54,65]$. As a result, the genes involved in the anatomical, physiological, and biochemical aspects are regulated directly and/or indirectly via a simultaneous defense network. The omics-mediated responses include photosynthesis, biosynthesis, antioxidants, photoprotection, cell membrane stability, osmoprotection, water status, leaf senescence, and oxidative damage alleviation, in addition to the anatomical changes. Consequently, the whole plant status is enhanced, including growth and development, flowering, yield, quality, and survival rate (recovering after rehydration), while the toxic substances are decreased, which collectively lead to drought tolerance.

\subsubsection{Melatonin Orchestrates other Phytohormones in the Regulatory-Defense Network}

Melatonin is a central molecule in the hormonal system and, thus, increases plant tolerance to drought stress through the regulation of phytohormone levels such as abscisic acid (ABA), auxins (Auxs), cytokinins (CKs), gibberellins (GAs), brassinosteroids (BRs), jasmonic acid (JA), and salicylic acid (SA). The key physiological aspects that are much regulated by phytohormones in response to drought stress include antioxidant metabolism, carbohydrate production (carbon metabolism), stomatal movement, and leaf senescence [82]. Drought stress upregulates ABA, BRs, and JA [59,82] and downregulates CKs and GAs [51,59], while melatonin enhances the levels of BRs, GAs, JA, and CKs [59] and decreases the ABA level [59] (Figure 2). 


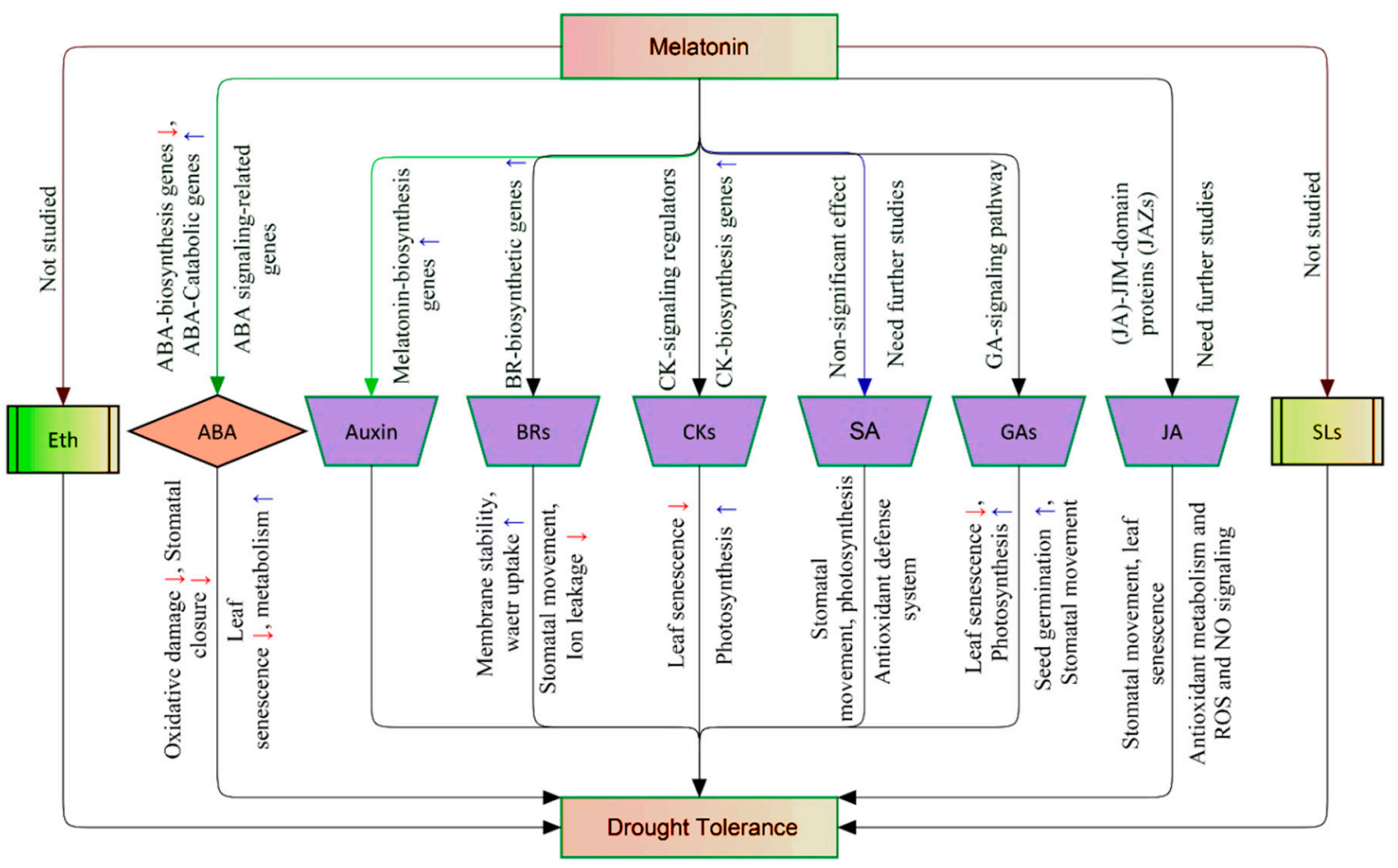

Figure 2. A schematic model explaining the effect of melatonin on other phytohormones under drought stress: Under drought, melatonin enhances the levels of brassinosteroids (BRs), cytokinins (CKs), gibberellins (GAs), and jasmonates (JAs) and decreases the abscisic acid (ABA) level and auxins. Eth, ethylene; ABA, abscisic acid; BRs, brassinosteroids; CKs, cytokinins; SA, salicylic acid; GAs, gibberellins; JA, jasmonic acid; SLs, strigolactones. Red connectors, not studied; green connectors, reduced; black connectors, enhanced; blue connectors, nonsignificant effect. $\uparrow$, upregulated; $\downarrow$, downregulated.

Water scarcity stimulates abscisic acid (ABA) biosynthesis [13,83], which in turn downregulates the main metabolic pathways [59], induces stomatal closure [82], and contributes to leaf senescence [82]. Moreover, the overaccumulation of abscisic acid upregulates the ROS generation pathways and causes oxidative damage [13]. However, melatonin maintains the abscisic acid homeostasis (low to moderate concentrations) by positive regulation of its biosynthetic genes and negative regulation of the catabolic genes [49,51,53,59]. Li et al. [53] clarified that melatonin effectively downregulates MdNCED3, an abscisic acid synthesis gene, and upregulates its catabolic genes, MdCYP707A2 and MdCYP707A1, causing abscisic acid reduction. Moreover, melatonin regulates abscisic acid signaling-related genes such as SnRK2 (SNF1-related protein kinases 2), RCAR/PYR/PYL, and NCED (nine-cis-epoxycarotenoid dioxygenase) [67]. Cytokinins (CKs) are an essential group of phytohormones in the inhibition of leaf senescence and chlorophyll degradation under water stress, which in turn suppresses cytokinin biosynthesis and transport, causing cytokinin reduction and faster leaf senescence [84-86]. Melatonin treatment upregulates cytokininlevels and some related signaling factors, leading to better photosynthesis efficiency and drought-induced tolerance $[59,65,87]$. The first demonstration that melatonin inhibits leaf senescence was made in barley [88]. Melatonin-induced alleviation of leaf senescence in creeping bentgrass is associated with the downregulation of chlorophyll catabolism and synergistic interaction with cytokinins-biosynthesis genes and signaling pathways in melatonin-treated ipt-transgenic plants [65].

Brassinosteroids (BRs) possess an apparent ability as drought stress-protective molecules in plants [89]. Melatonin regulates the biosynthesis of brassinosteroidsvia the stimulation of various brassinosteroid-biosynthetic genes like DWARF4, D11, and RAVL1 [90], which control stomatal movement [91], enhance cell membrane constancy and water uptake, and decrease membrane damage-induced ion leakage in the case of water limitation [59,92]. Jasmonic acid (JA) is a crucial plant 
hormone in the regulation of drought responses such as stomatal movement, leaf senescence, antioxidant metabolism, and ROS and nitro-oxide signaling [93-98]. Jasmonic acid levels are increased in response to drought stress and are highly stimulated as a result of melatonin application, which induces drought tolerance [59]. The melatonin-jasmonic acid crosstalk is stated by regulating molecular transcripts such as JA-JIM-domain proteins (JAZs) in jasmonic acid signaling [67].

Moreover, melatonin interacts with gibberellins (GAs) via GA-signaling, which further controls the biosynthesis of auxins [24,59]. Gibberellins are regulators of stomatal movement [99,100], photosynthesis [101], seed germination [102], and leaf senescence [4]. Drought stress inhibits gibberellin biosynthesis [51,103], which is much enhanced in response to melatonin treatment, causing drought tolerance [59]. Salicylic acid (SA) accumulation plays a vital role in stomatal movement, photosynthesis, and the antioxidant defense system [4]. In maize plants, under drought conditions, an increase (but nonsignificant) in the defense hormonesalicylic acid has been described in melatonin-treated plants [34]. Enhanced drought tolerance was achieved using mainly transgenic plants through the overexpression of melatonin-biosynthesis genes under drought conditions [24,104,105], which led to a decrease of indole-3-acetic acid (IAA) that may be due to the competition for the same precursor, tryptophan. The plant root is the first plant organ to touch the environment, and it represents a priority for plant breeders to improve its efficiency under abiotic stresses, including drought. Interestingly, melatonin targets plant roots, showing an auxin-like action [106]. In this regard, Pelagio-Flores et al. [106] provided direct evidence supporting the mechanism of this action in Arabidopsis thaliana via inspiring lateral and adventitious root formation, conferring a widespread root system. The auxin-like effect of melatonin in roots was elucidated using auxin-responsive marker constructs. It was suggested that melatonin neither activates auxin-inducible gene expression nor induces the degradation of HS:AXR3NT-GUS, indicating that root developmental changes elicited by melatonin are independent of auxin signaling [106]. To date, under drought situations, there has been no comprehensive study revealing the interaction between melatonin and ethylene or strigolactones; thus, further investigations are needed. All the above details confirmed that melatonin acts as a relevant regulator of many plant hormone elements, a so-called plant master regulator $[107,108]$, making the plants more tolerant when irrigation water is limited (Figure 2).

\subsubsection{The Crosstalk of Melatonin, Nitric Oxide, and Hydrogen Sulfide in Melatonin-Water} Stress Research

Melatonin, nitric oxide (NO), and hydrogen sulfide $\left(\mathrm{H}_{2} \mathrm{~S}\right)$ are essential small molecules in the plant defense network [109]. Melatonin controls various plant responses under water stress, as described throughout the text. Nitric oxide is a fundamental signaling molecule working as a pro-oxidant and antioxidant element against adverse environments, which is determinant by its endogenous concentration and locational production status [110]. Hydrogen sulfide is a master metabolic regulator in plants, which alleviates the destructive effects of environmental stresses such as drought and waterlogging through the regulation of enzymatic antioxidants [111,112]. The relationship of melatonin, nitric oxide, and hydrogen sulfide has been studied in fruit ripening regulation [113], as well as under biotic [114] and abiotic stresses [110] such as salinity [115] and drought [52]. For instance, nitric oxide and ethylene crosstalk is mediated by hydrogen sulfide and melatonin activity, which regulate various metabolic pathways associated with fruit ripening [113]. Moreover, salt stress alone or combined with iron deficiency expands endogenous hydrogen sulfide and nitric oxide, which are much enhanced due to melatonin treatment [116]. To date, there has only been one published report addressing the relationship between melatonin and nitric oxide under water scarcity [52], while the melatonin-hydrogen sulfide relationship and the triple crosstalk of melatonin-nitric oxide-hydrogen sulfide under water stress remain unknown. In that report, the authors suggested that melatonin mitigates drought damage in alfalfa plants by modulating nitro-oxidative homeostasis through the regulation of reactive oxygen and nitrogen species metabolic enzymes at the enzymatic and/or transcript level [52]. However, how endogenous melatonin interacts with nitric oxide under water scarcity is 
still a research point [110]. The question that still needs to be answered is whether the crosstalk of melatonin, nitric oxide, and hydrogen sulfide under water stress is similar to the situation under other environmental stresses or if they have a unique interaction in each situation.

\section{Melatonin-Induced Waterlogging Stress Tolerance}

\subsection{An Overview}

Despite the importance of melatonin in mitigating the harmful effects of abiotic stresses, the research on melatonin-induced waterlogging tolerance has only recently started to emerge (Table 2). The first report was registered as a patent in 2015 by Chen et al. [117]. In this report, the authors indicated that melatonin has a great ability to eliminate ROS, alleviate oxidative damage, resist waterlogging, and, consequently, revert losses in yield and quality [117]. After this ground-breaking work, Zheng et al. [118] elucidated that melatonin is an effective phytohormone to protect apple plants under waterlogging stress. Melatonin application improved endogenous melatonin levels, antioxidant enzyme activities, chlorophyll content and photosynthesis, and aerobic respiration, while it suppressed chlorosis, wilting, ROS, malondialdehyde, and anaerobic respiration [118]. Moreover, melatonin-biosynthesis enzymes ( $\mathrm{MbT5H1}, \mathrm{MbAANAT3}$, and MbASMT9) were upregulated due to melatonin treatment [118]. In recent work, Zhang et al. [119] investigated the impact of melatonin pretreatment on alfalfa under waterlogging stress and indicated that melatonin could alleviate the stress damage and enhance plant growth, chlorophyll content, and PSII efficiency. Moreover, melatonin treatment increased polyamine (putrescine, spermidine, and spermine) levels and decreased ethylene under stress, which are controlled via changes in gene expression [119].

Table 2. Roles of melatonin in waterlogging stress tolerance.

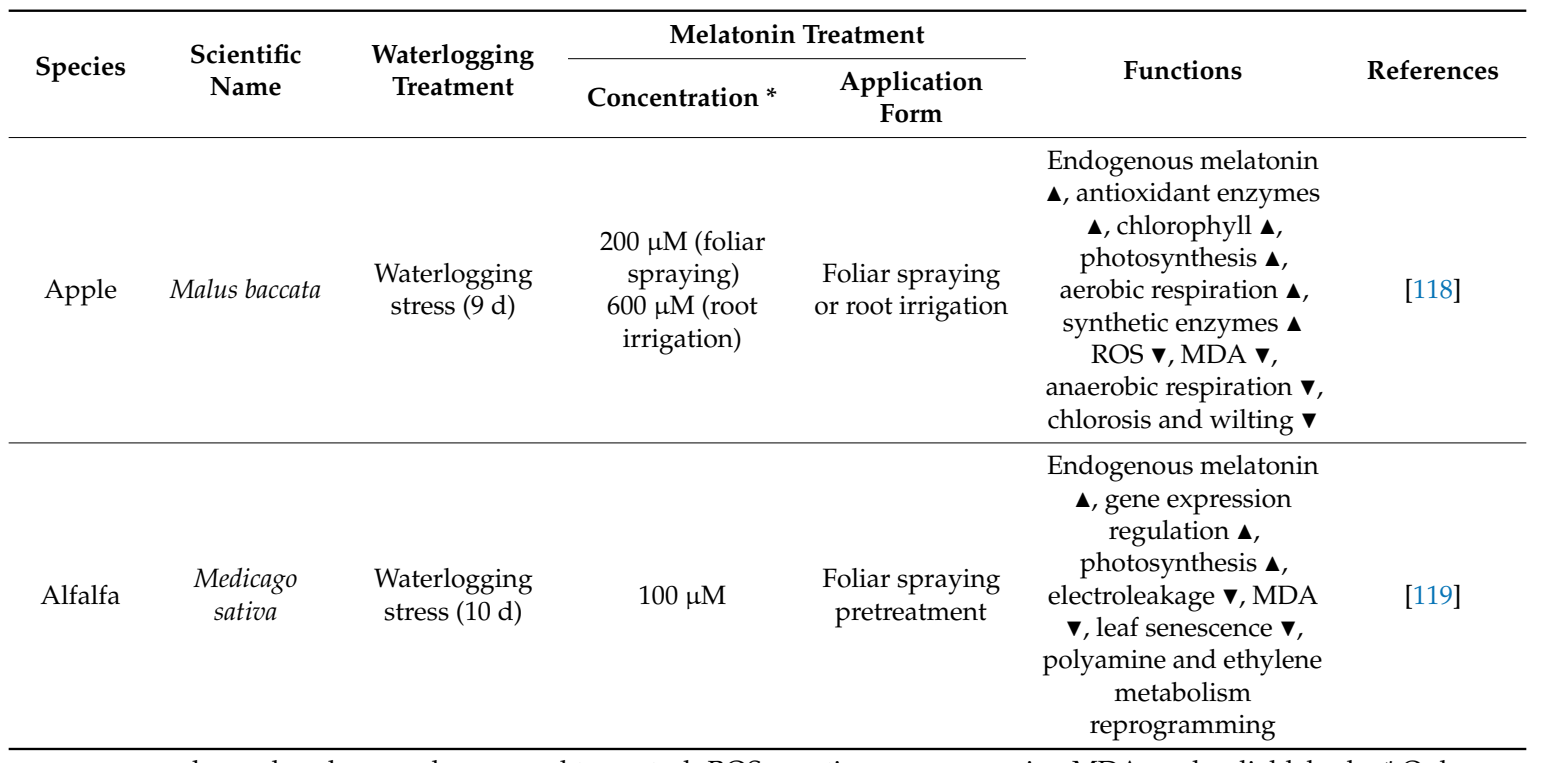

$\boldsymbol{\Delta}$ or $\mathbf{\nabla}$, enhanced or decreased compared to control. ROS, reactive oxygen species; MDA, malondialdehyde. ${ }^{*}$ Only those doses of exogenous melatonin that had a superior positive impact on plant tolerance against waterlogging stress have been selected.

\subsection{Mechanisms of Melatonin-Mediated Waterlogging Stress Tolerance}

Melatonin application is a practical approach to suppress the drastic effects of waterlogging (Figure 3). To date, there are two published mechanisms induced by melatonin to enforce waterlogging tolerance [118,119]. Zheng et al. [118] proposed the first mechanism of melatonin-mediated waterlogging tolerance in apple seedlings, which keeps aerobic respiration and preserves photosynthesis by efficient repression of the ROS burst and consequent mitochondrial degradation. Zhang et al. [119] suggested another model in alfalfa through interaction with or direct regulation of the metabolic 
pathways of ethylene and polyamines (PAs). Waterlogging stress induced an increase of endogenous melatonin levels of 2- to 5-fold compared with unstressed plants. Melatonin starts by reducing ethylene production via the downregulation of ethylene synthesis-associated genes and alleviation of waterlogging-caused growth inhibition, chlorosis, and premature senescence [119]. Then, melatonin enhances polyamines levels by promoting the gene expression of the involved enzymes in polyamine metabolism [119]. The authors proposed that melatonin increases waterlogging tolerance, at least partially, by regulating polyamines and ethylene biosynthesis due to ethylene suppression and polyamine promotion, leading to more stable cell membranes, better photosynthesis, and less ethylene-responsive senescence [119].

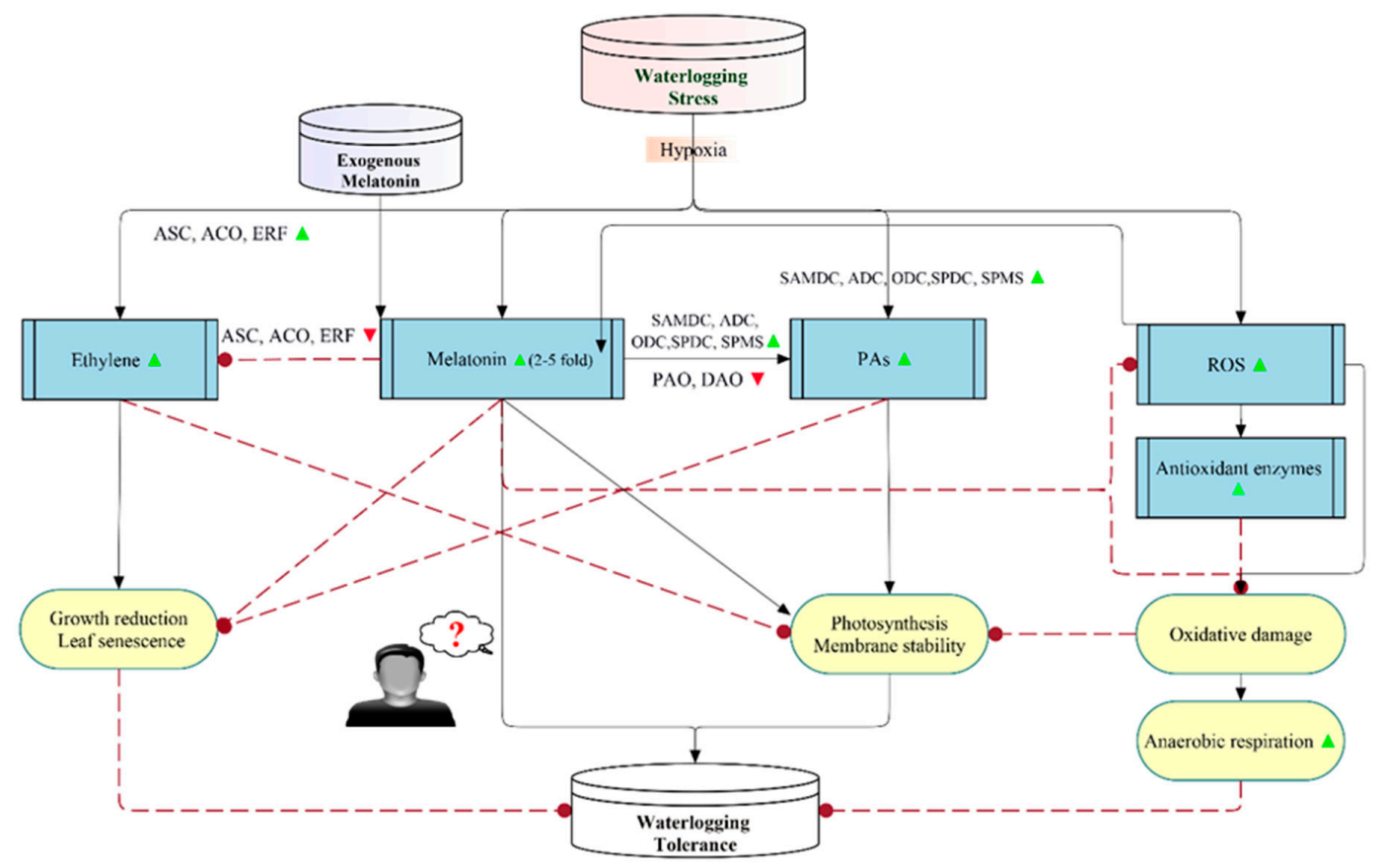

Figure 3. Schematic model explaining the protective mechanisms of melatonin in waterlogging tolerance. The solid arrows indicate stimulation, while the dashes indicate inhibition. $\mathbf{\Delta}$ and $\mathbf{\nabla}$ shapes indicate enhanced or decreased levels, respectively. Waterlogging induces ethylene, melatonin (2- to 5 -fold), polyamines (PAs), and reactive oxygen species (ROS). Melatonin is also induced in response to ROS generation and exogenous melatonin. Melatonin stimulates PA biosynthesis, photosynthesis, and membrane stability, while it inhibits ethylene biosynthesis, growth reduction, leaf senescence, ROS, and oxidative damage. Excessive ROS causes oxidative damage leading to anaerobic respiration, which is scavenged by antioxidant enzymes. Additionally, growth reduction and leaf senescence are increased by ethylene, while they are decreased by PAs. Moreover, photosynthesis and membrane stability is enhanced by PAs, while they are reduced by ethylene induction and oxidative damage. The role of melatonin in waterlogging tolerance still needs further study. This figure is a combination of the two published mechanisms of Zheng et al. [118] and Zhang et al. [119], with some modifications.

Collectively, waterlogging induces ethylene, melatonin (2- to 5-fold), polyamines (PAs), and ROS. Melatonin is also produced in response to ROS generation and exogenous melatonin. Melatonin stimulates polyamines biosynthesis, photosynthesis, and membrane stability, while it inhibits ethylene biosynthesis, growth reduction, leaf senescence, ROS, and oxidative damage. Excessive ROS causes oxidative damage leading to anaerobic respiration, which is scavenged by antioxidant enzymes. Additionally, growth reduction and leaf senescence are increased by ethylene, while they are decreased by polyamines. Moreover, photosynthesis and membrane stability are enhanced by polyamines, while they are reduced by ethylene induction and oxidative damage (Figure 3). The role of melatonin in waterlogging tolerance, especially molecular evidence, still needs further study. 


\section{Conclusions}

Water stress tolerance (drought stress and waterlogging) may be attributed to structural and functional adaptations at the cellular and whole-plant levels, including root enhancement, growth promotion, oxidative damage alleviation, osmotic potential modulation, leaf water potential, cell wall elasticity control, stomatal closure, and the accumulation of osmolytes, thereby easing the harmful impacts of such destructive stresses $[4,14]$. Melatonin may be considered a core part of the regulatory network controlling all of these mechanisms, and it represents a promising material for future studies and practical use $[18,107,108]$. Melatonin research has been experiencing hypergrowth in the last two decades; however, its roles in water stress tolerance need further investigation. The regulation of melatonin and its metabolism pathway under water stress is still unclear. Understanding the role of melatonin in nutrient uptake will give us an excellent opportunity to take advantage of such a useful molecule for strengthening plant tolerance and adaptability to water stress. Furthermore, in-depth studies to clarify the molecular mechanisms using microarray, transcriptomic, and proteomic analyses will help to figure out the genes regulating plant anatomical, physiological, and biochemical aspects in response to exogenous melatonin applications under water stress. Exploring new receptor-mediated phytomelatonin signaling plays a role in such physiological processes in future works. Additionally, the best-known information on the relationship of melatonin with other small signaling molecules, such as $\mathrm{NO}$ and $\mathrm{H}_{2} \mathrm{~S}$, can be relevant. In recent decades, significant advancement in the knowledge of the mechanism of $\mathrm{NO}$ and $\mathrm{H}_{2} \mathrm{~S}$ signaling and their crosstalk with melatonin has been made [113,115]. Therefore, the distribution of melatonin in plant organs and their interrelations with $\mathrm{NO}$ and $\mathrm{H}_{2} \mathrm{~S}$ should be further studied [115]. The molecular mechanisms revealing the crosstalk between melatonin and other phytohormones such as strigolactones and ethylene in promoting water stress tolerance are worth further studies on mutagenesis or genetic modulation and aquatic model plants. The relationship between melatonin and multiple stressor combinations is a topic to be taken into account in future research due to the complexity of the interaction of plants with diverse environmental agents. Lastly, the use of synthetic melatonin, a relatively cheap compound, or phytomelatonin-rich extracts should be an interesting approach to improving plant tolerance $[120,121]$.

Author Contributions: M.M.-F. and A.M. contributed to the writing of the first draft of the manuscript. M.B.A., M.S., M.D., M.S.S., A.E., and M.H. contributed to the planning of the main ideas, visualization, and the revision of the manuscript. S.A. was the team leader and mentor. All authors have read and agreed to the published version of the manuscript.

Funding: This work was financially supported by the Dean Funding Project Scheme of the Guangdong Academy of Agricultural Sciences, Guangzhou, China (No. 201811B). Science and Technology Planning Project of Guangdong Province (No. 2016B020240009).

Acknowledgments: M.M.-F. would like to thank his group team at Guangdong Academy of Agriculture Sciences, Yichun Li, Linfeng Li, Mingdeng Tang, and Yanhong Wang, for their support and cooperation during the writing of this review. Also, thanks to Osama ElSawah for his help in improving quality of the figures.

Conflicts of Interest: The authors declare that there is no conflict of interest.

\section{References}

1. Xoconostle-Cázares, B.; Ramirez-Ortega, F.A.; Flores-Elenes, L.; Ruiz-Medrano, R. Drought tolerance in crop plants. Am. J. Plant Physiol. 2010, 5, 1-16.

2. Stuart, M.E.; Gooddy, D.C.; Bloomfield, J.P.; Williams, A.T. A review of the impact of climate change on future nitrate concentrations in groundwater of the UK. Sci. Total Environ. 2011, 409, 2859-2873. [CrossRef] [PubMed]

3. Jackson, M.B.; Colmer, T.D. Response and adaptation by plants to flooding stress. Ann. Bot. 2005, 96, 501-505. [CrossRef] [PubMed]

4. Hasanuzzaman, M.; Islam, M.T.; Nahar, K.; Anee, T.I. Drought stress tolerance in wheat: Omics approaches in enhancing antioxidant defense. In Abiotic Stress-Mediated Sensing and Signaling in Plants: An Omics Perspective; Zargar, S.M., Ed.; Springer: New York, NY, USA, 2016; pp. 267-307. 
5. Arbona, V.; Hossain, Z.; Lopez-Climent, M.F.; Perez-Clemente, R.M.; Gomez-Cadenas, A. Antioxidant enzymatic activity is linked to waterlogging stress tolerance in citrus. Physiol. Plant. 2008, 132, 452-466. [CrossRef] [PubMed]

6. Hossain, Z.; Lopez-Climent, M.F.; Arbona, V.; Perez-Clemente, R.M.; Gomez-Cadenas, A. Modulation of the antioxidant system in Citrus under waterlogging and subsequent drainage. J. Plant Physiol. 2009, 166, 1391-1404. [CrossRef] [PubMed]

7. Boru, G.; Vantoai, T.; Alves, J.; Hua, D.; Knee, M. Responses of Soybean to Oxygen Deficiency and Elevated Root-zone Carbon Dioxide Concentration. Ann. Bot. 2003, 91, 447-453. [CrossRef]

8. Laxa, M.; Liebthal, M.; Telman, W.; Chibani, K.; Dietz, K.J. The Role of the Plant Antioxidant System in Drought Tolerance. Antioxidants 2019, 8, 94. [CrossRef]

9. Daryanto, S.; Wang, L.; Jacinthe, P.-A. Global synthesis of drought effects on maize and wheat production. PLoS ONE 2016, 11, e0156362. [CrossRef]

10. Voesenek, L.A.; Sasidharan, R. Ethylene-and oxygen signalling-drive plant survival during flooding. Plant Biol. 2013, 15, 426-435. [CrossRef]

11. Shabala, S.; Shabala, L.; Barcelo, J.; Poschenrieder, C. Membrane transporters mediating root signalling and adaptive responses to oxygen deprivation and soil flooding. Plant Cell Environ. 2014, 37, 2216-2233. [CrossRef]

12. Dennis, E.S.; Dolferus, R.; Ellis, M.; Rahman, M.; Wu, Y.; Hoeren, F.U.; Grover, A.; Ismond, K.P.; Good, A.G.; Peacock, W.J. Molecular strategies for improving waterlogging tolerance in plants. J. Exp. Bot. 2000, 51, 89-97. [CrossRef] [PubMed]

13. Elkeilsh, A.; Awad, Y.M.; Soliman, M.H.; Abu-Elsaoud, A.; Abdelhamid, M.T.; El-Metwally, I.M. Exogenous application of $\beta$-sitosterol mediated growth and yield improvement in water-stressed wheat (Triticum aestivum) involves up-regulated antioxidant system. J. Plant Res. 2019, 132, 881-901. [CrossRef] [PubMed]

14. Tewari, S.; Mishra, A. Flooding Stress in Plants and Approaches to Overcome. In Plant Metabolites and Regulation under Environmental Stress; Elsevier: Amsterdam, The Netherlands, 2018; pp. 355-366.

15. Verma, V.; Ravindran, P.; Kumar, P.P. Plant hormone-mediated regulation of stress responses. BMC Plant Biol. 2016, 16, 86. [CrossRef] [PubMed]

16. Arnao, M.B.; Hernández-Ruiz, J. Melatonin: A New Plant Hormone and/or a Plant Master Regulator? Trends Plant Sci. 2019, 24, 38-48. [CrossRef] [PubMed]

17. Sharma, A.; Zheng, B. Melatonin Mediated Regulation of Drought Stress: Physiological and Molecular Aspects. Plants 2019, 8, 190. [CrossRef] [PubMed]

18. Ahmad, S.; Cui, W.; Kamran, M.; Ahmad, I.; Meng, X.; Wu, X.; Su, W.; Javed, T.; El-Serehy, H.A.; Jia, Z.; et al. Exogenous Application of Melatonin Induces Tolerance to Salt Stress by Improving the Photosynthetic Efficiency and Antioxidant Defense System of Maize Seedling. J. Plant Growth Regul. 2020, 2020, 1-14. [CrossRef]

19. Sharif, R.; Xie, C.; Zhang, H.; Arnao, M.B.; Ali, M.; Ali, Q.; Muhammad, I.; Shalmani, A.; Nawaz, M.A.; Chen, P.; et al. Melatonin and Its Effects on Plant Systems. Molecules 2018, 23, 2352. [CrossRef]

20. Moustafa-Farag, M.; Almoneafy, A.; Mahmoud, A.; Elkelish, A.; Arnao, M.B.; Li, L.; Ai, S. Melatonin and Its Protective Role against Biotic Stress Impacts on Plants. Biomolecules 2020, 10, 54. [CrossRef]

21. Bose, S.K.; Howlader, P. Melatonin plays multifunctional role in horticultural crops against environmental stresses: A review. Environ. Exp. Bot. 2020, 176, 104063. [CrossRef]

22. Arnao, M.B.; Hernandez-Ruiz, J. Functions of melatonin in plants: A review. J. Pineal Res. 2015, 59, $133-150$. [CrossRef]

23. Back, K.; Lee, H.-J. 2-Hydroxymelatonin confers tolerance against combined cold and drought stress in tobacco, tomato, and cucumber as a potent anti-stress compound in the evolution of land plants. Melatonin Res. 2019, 2, 35-46.

24. Yang, W.J.; Du, Y.T.; Zhou, Y.B.; Chen, J.; Xu, Z.S.; Ma, Y.Z.; Chen, M.; Min, D.H. Overexpression of TaCOMT Improves Melatonin Production and Enhances Drought Tolerance in Transgenic Arabidopsis. Int. J. Mol. Sci. 2019, 20, 652. [CrossRef] [PubMed]

25. Cao, L.; Jin, X.J.; Zhang, Y.X. Melatonin confers drought stress tolerance in soybean (Glycine max L.) by modulating photosynthesis, osmolytes, and reactive oxygen metabolism. Photosynthetica 2019, 57, 812-819. [CrossRef] 
26. Su, X.; Fan, X.; Shao, R.; Guo, J.; Wang, Y.; Yang, J.; Yang, Q.; Guo, L. Physiological and iTRAQ-based proteomic analyses reveal that melatonin alleviates oxidative damage in maize leaves exposed to drought stress. Plant Physiol. Biochem. 2019, 142, 263-274. [CrossRef] [PubMed]

27. Xia, H.; Ni, Z.; Hu, R.; Lin, L.; Deng, H.; Wang, J.; Tang, Y.; Sun, G.; Wang, X.; Li, H.; et al. Melatonin Alleviates Drought Stress by a Non-Enzymatic and Enzymatic Antioxidative System in Kiwifruit Seedlings. Int. J. Mol. Sci. 2020, 21, 852. [CrossRef]

28. Lin, Z.; Wang, Y.; Xia, H.; Liang, D. Effects of exogenous melatonin and abscisic acid on the antioxidant enzyme activities and photosynthetic pigment in 'Summer Black' grape under drought stress. IOP Conf. Ser. Earth Environ. Sci. 2019, 295, 012013. [CrossRef]

29. Karaca, P.; Cekic, F.Ö. Exogenous melatonin-stimulated defense responses in tomato plants treated with polyethylene glycol. Int. J. Veg. Sci. 2019, 25, 601-609. [CrossRef]

30. Kaya, A.; Doganlar, Z.B. Melatonin improves the multiple stress tolerance in pepper (Capsicum annuum). Sci. Hortic. 2019, 256, 108509. [CrossRef]

31. Campos, C.N.; Avila, R.G.; Dazio de Souza, K.R.; Azevedo, L.M.; Alves, J.D. Melatonin reduces oxidative stress and promotes drought tolerance in young Coffea arabica L. plants. Agric. Water Manag. 2019, 211, 37-47. [CrossRef]

32. Li, J.; Yang, Y.; Sun, K.; Chen, Y.; Chen, X.; Li, X. Exogenous Melatonin Enhances Cold, Salt and Drought Stress Tolerance by Improving Antioxidant Defense in Tea Plant (Camellia sinensis (L.) O. Kuntze). Molecules 2019, 24, 1826. [CrossRef]

33. Meng, J.F.; Xu, T.F.; Wang, Z.Z.; Fang, Y.L.; Xi, Z.M.; Zhang, Z.W. The ameliorative effects of exogenous melatonin on grape cuttings under water-deficient stress: Antioxidant metabolites, leaf anatomy, and chloroplast morphology. J. Pineal Res. 2014, 57, 200-212. [CrossRef] [PubMed]

34. Fleta-Soriano, E.; Díaz, L.; Bonet, E.; Munné-Bosch, S. Melatonin may exert a protective role against drought stress in maize. J. Agron. Crop Sci. 2017, 203, 286-294. [CrossRef]

35. Khan, M.N.; Zhang, J.; Luo, T.; Liu, J.; Rizwan, M.; Fahad, S.; Xu, Z.; Hu, L. Seed priming with melatonin coping drought stress in rapeseed by regulating reactive oxygen species detoxification: Antioxidant defense system, osmotic adjustment, stomatal traits and chloroplast ultrastructure perseveration. Ind. Crop. Prod. 2019, 140, 111597. [CrossRef]

36. Wei, W.; Li, Q.T.; Chu, Y.N.; Reiter, R.J.; Yu, X.M.; Zhu, D.H.; Zhang, W.K.; Ma, B.; Lin, Q.; Zhang, J.S.; et al. Melatonin enhances plant growth and abiotic stress tolerance in soybean plants. J. Exp. Bot. 2015, 66, 695-707. [CrossRef] [PubMed]

37. Ding, Z.; Wu, C.; Tie, W.; Yan, Y.; He, G.; Hu, W. Strand-specific RNA-seq based identification and functional prediction of lncRNAs in response to melatonin and simulated drought stresses in cassava. Plant Physiol. Biochem. 2019, 140, 96-104. [CrossRef]

38. Zou, J.N.; Jin, X.J.; Zhang, Y.X.; Ren, C.Y.; Zhang, M.C.; Wang, M.X. Effects of melatonin on photosynthesis and soybean seed growth during grain filling under drought stress. Photosynthetica 2019, 57, 512-520. [CrossRef]

39. Li, H.; Mo, Y.; Cui, Q.; Yang, X.; Guo, Y.; Wei, C.; Yang, J.; Zhang, Y.; Ma, J.; Zhang, X. Transcriptomic and physiological analyses reveal drought adaptation strategies in drought-tolerant and -susceptible watermelon genotypes. Plant Sci. 2019, 278, 32-43. [CrossRef]

40. Shi, H.; Qian, Y.; Tan, D.X.; Reiter, R.J.; He, C. Melatonin induces the transcripts of CBF/DREB1s and their involvement in both abiotic and biotic stresses in Arabidopsis. J. Pineal Res. 2015, 59, 334-342. [CrossRef]

41. Lee, H.-J.; Back, K. 2-Hydroxymelatonin promotes the resistance of rice plant to multiple simultaneous abiotic stresses (combined cold and drought). J. Pineal Res. 2016, 61, 303-316. [CrossRef]

42. Ye, J.; Wang, S.; Deng, X.; Yin, L.; Xiong, B.; Wang, X. Melatonin increased maize (Zea mays L.) seedling drought tolerance by alleviating drought-induced photosynthetic inhibition and oxidative damage. Acta Physiol. Plant. 2016, 38, 48. [CrossRef]

43. Huang, B.; Chen, Y.E.; Zhao, Y.Q.; Ding, C.B.; Liao, J.Q.; Hu, C.; Zhou, L.J.; Zhang, Z.W.; Yuan, S.; Yuan, M. Exogenous Melatonin Alleviates Oxidative Damages and Protects Photosystem II in Maize Seedlings Under Drought Stress. Front. Plant Sci. 2019, 10, 677. [CrossRef] [PubMed]

44. Ahmad, S.; Kamran, M.; Ding, R.; Meng, X.; Wang, H.; Ahmad, I.; Fahad, S.; Han, Q. Exogenous melatonin confers drought stress by promoting plant growth, photosynthetic capacity and antioxidant defense system of maize seedlings. PeerJ 2019, 7, e7793. [CrossRef] [PubMed] 
45. Cui, G.; Zhao, X.; Liu, S.; Sun, F.; Zhang, C.; Xi, Y. Beneficial effects of melatonin in overcoming drought stress in wheat seedlings. Plant Physiol. Biochem. 2017, 118, 138-149. [CrossRef] [PubMed]

46. Ye, J.; Deng, X.P.; Wang, S.W.; Yin, L.N.; Chen, D.Q.; Xiong, B.L.; Wang, X.Y. Effects of melatonin on growth, photosynthetic characteristics and antioxidant system in seedling of wheat under drought stress. J. Triticeae Crop. 2015, 35, 1275-1283.

47. Li, D.; Zhang, D.; Wang, H.; Li, H.; Song, S.; Li, H.; Li, R. Effects of melatonin on germination and amino acid content in different wheat varieties seeds under polyethylene glycol stress. BioRxiv 2019, 2019, 710954.

48. Hossain, M.S.; Li, J.; Sikdar, A.; Hasanuzzaman, M.; Uzizerimana, F.; Muhammad, I.; Yuan, Y.; Zhang, C.; Wang, C.; Feng, B. Exogenous Melatonin Modulates the Physiological and Biochemical Mechanisms of Drought Tolerance in Tartary Buckwheat (Fagopyrum tataricum (L.) Gaertn). Molecules 2020, 25, 2828. [CrossRef]

49. Li, X.; Tan, D.X.; Jiang, D.; Liu, F. Melatonin enhances cold tolerance in drought-primed wild-type and abscisic acid-deficient mutant barley. J. Pineal Res. 2016, 61, 328-339. [CrossRef]

50. Zhang, M.; He, S.; Zhan, Y.; Qin, B.; Jin, X.; Wang, M.; Zhang, Y.; Hu, G.; Teng, Z.; Wu, Y. Exogenous melatonin reduces the inhibitory effect of osmotic stress on photosynthesis in soybean. PLOS ONE 2019, 14, e0226542. [CrossRef]

51. Bai, Y.; Xiao, S.; Zhang, Z.; Zhang, Y.; Sun, H.; Zhang, K.; Wang, X.; Bai, Z.; Li, C.; Liu, L. Melatonin improves the germination rate of cotton seeds under drought stress by opening pores in the seed coat. PeerJ 2020, 8, e9450. [CrossRef]

52. Antoniou, C.; Chatzimichail, G.; Xenofontos, R.; Pavlou, J.J.; Panagiotou, E.; Christou, A.; Fotopoulos, V. Melatonin systemically ameliorates drought stress-induced damage in Medicago sativa plants by modulating nitro-oxidative homeostasis and proline metabolism. J. Pineal Res. 2017, 62, e12401. [CrossRef]

53. Li, C.; Tan, D.X.; Liang, D.; Chang, C.; Jia, D.; Ma, F. Melatonin mediates the regulation of ABA metabolism, free-radical scavenging, and stomatal behaviour in two Malus species under drought stress. J. Exp. Bot. 2015, 66, 669-680. [CrossRef] [PubMed]

54. Liang, B.; Ma, C.; Zhang, Z.; Wei, Z.; Gao, T.; Zhao, Q.; Ma, F.; Li, C. Long-term exogenous application of melatonin improves nutrient uptake fluxes in apple plants under moderate drought stress. Environ. Exp. Bot. 2018, 155, 650-661. [CrossRef]

55. Wang, P.; Sun, X.; Li, C.; Wei, Z.; Liang, D.; Ma, F. Long-term exogenous application of melatonin delays drought-induced leaf senescence in apple. J. Pineal Res. 2013, 54, 292-302. [CrossRef] [PubMed]

56. Jiao, J.; Ma, Y.; Chen, S.; Liu, C.; Song, Y.; Qin, Y.; Yuan, C.; Liu, Y. Melatonin-producing endophytic bacteria from grapevine roots promote the abiotic stress-induced production of endogenous melatonin in their hosts. Front. Plant Sci. 2016, 7, 1387. [CrossRef] [PubMed]

57. Niu, X.; Deqing, C.; Liang, D. Effects of exogenous melatonin and abscisic acid on osmotic adjustment substances of 'Summer Black' grape under drought stress. IOP Conf. Ser. Earth Environ. Sci. 2019, 295, 012012. [CrossRef]

58. Liang, D.; Ni, Z.; Xia, H.; Xie, Y.; Lv, X.; Wang, J.; Lin, L.; Deng, Q.; Luo, X. Exogenous melatonin promotes biomass accumulation and photosynthesis of kiwifruit seedlings under drought stress. Sci. Hortic. 2019, 246, 34-43. [CrossRef]

59. Sharma, A.; Wang, J.; Xu, D.; Tao, S.; Chong, S.; Yan, D.; Li, Z.; Yuan, H.; Zheng, B. Melatonin regulates the functional components of photosynthesis, antioxidant system, gene expression, and metabolic pathways to induce drought resistance in grafted Carya cathayensis plants. Sci. Total Environ. 2020, 713, 136675. [CrossRef]

60. Liu, J.; Wang, W.; Wang, L.; Sun, Y. Exogenous melatonin improves seedling health index and drought tolerance in tomato. Plant Growth Regul. 2015, 77, 317-326. [CrossRef]

61. Zhang, N.; Zhao, B.; Zhang, H.-J.; Weeda, S.; Yang, C.; Yang, Z.-C.; Ren, S.; Guo, Y.-D. Melatonin promotes water-stress tolerance, lateral root formation, and seed germination in cucumber (Cucumis sativus L.). J. Pineal Res. 2013, 54, 15-23. [CrossRef]

62. Li, J.; Zeng, L.; Cheng, Y.; Lu, G.; Fu, G.; Ma, H.; Liu, Q.; Zhang, X.; Zou, X.; Li, C. Exogenous melatonin alleviates damage from drought stress in Brassica napus L. (rapeseed) seedlings. Acta Physiol. Plant. 2018, 40, 43. [CrossRef]

63. Yan, W.; Hongyan, L.; Xuejiao, M.; Xuejuan, W.; Yuanbing, Z. Effect of Foliar Spraying Exogenous Melatonin on Physiological and Biochemical Characteristics of Dendranthema morifolium. Acta Bot. Boreali-Occident. Sin. 2016, 36, 2241-2246. 
64. Kabiri, R.; Hatami, A.; Oloumi, H.; Naghizadeh, M.; Nasibi, F.; Tahmasebi, Z. Foliar application of melatonin induces tolerance to drought stress in Moldavian balm plants (Dracocephalum moldavica) through regulating the antioxidant system. Folia Hortic. 2018, 30, 155-167. [CrossRef]

65. Ma, X.; Zhang, J.; Burgess, P.; Rossi, S.; Huang, B. Interactive effects of melatonin and cytokinin on alleviating drought-induced leaf senescence in creeping bentgrass (Agrostis stolonifera). Environ. Exp. Bot. 2018, 145, 1-11. [CrossRef]

66. Alam, M.N.; Wang, Y.; Chan, Z. Physiological and biochemical analyses reveal drought tolerance in cool-season tall fescue (Festuca arundinacea) turf grass with the application of melatonin. Crop Past. Sci. 2018, 69, 1041-1049. [CrossRef]

67. Shi, H.; Jiang, C.; Ye, T.; Tan, D.-X.; Reiter, R.J.; Zhang, H.; Liu, R.; Chan, Z. Comparative physiological, metabolomic, and transcriptomic analyses reveal mechanisms of improved abiotic stress resistance in bermudagrass [Cynodon dactylon (L). Pers.] by exogenous melatonin. J. Exp. Bot. 2015, 66, 681-694. [CrossRef] [PubMed]

68. Zamani, Z.; Amiri, H.; Ismaili, A. Improving drought stress tolerance in fenugreek (Trigonella foenum-graecum) by exogenous melatonin. Plant Biosyst. 2019, 2019, 1-13. [CrossRef]

69. Arnao, M.B.; Hernández-Ruiz, J. Growth conditions determine different melatonin levels in Lupinus albus L. J. Pineal Res. 2013, 55, 149-155. [CrossRef]

70. Arnao, M.B.; Hernández-Ruiz, J. Chemical stress by different agents affects the melatonin content of barley roots. J. Pineal Res. 2009, 46, 295-299. [CrossRef]

71. Arnao, M.B.; Hernández-Ruiz, J. Growth conditions influence the melatonin content of tomato plants. Food Chem. 2013, 138, 1212-1214. [CrossRef]

72. Wei, Y.; Zeng, H.; Hu, W.; Chen, L.; He, C.; Shi, H. Comparative Transcriptional Profiling of Melatonin Synthesis and Catabolic Genes Indicates the Possible Role of Melatonin in Developmental and Stress Responses in Rice. Front. Plant Sci 2016, 7, 676. [CrossRef]

73. Arnao, M.B.; Hernández-Ruiz, J. Role of Melatonin to Enhance Phytoremediation Capacity. Appl. Sci. 2019, 9, 5293. [CrossRef]

74. Ding, F.; Wang, G.; Wang, M.; Zhang, S. Exogenous Melatonin Improves Tolerance to Water Deficit by Promoting Cuticle Formation in Tomato Plants. Molecules 2018, 23, 1605. [CrossRef] [PubMed]

75. Tan, D.X.; Manchester, L.C.; Liu, X.; Rosales-Corral, S.A.; Acuna-Castroviejo, D.; Reiter, R.J. Mitochondria and chloroplasts as the original sites of melatonin synthesis: A hypothesis related to melatonin's primary function and evolution in eukaryotes. J. Pineal Res. 2013, 54, 127-138. [CrossRef] [PubMed]

76. Back, K.; Tan, D.X.; Reiter, R.J. Melatonin biosynthesis in plants: Multiple pathways catalyze tryptophan to melatonin in the cytoplasm or chloroplasts. J. Pineal Res. 2016, 61, 426-437. [CrossRef] [PubMed]

77. Wei, J.; Li, D.X.; Zhang, J.R.; Shan, C.; Rengel, Z.; Song, Z.B.; Chen, Q. Phytomelatonin receptor PMTR1-mediated signaling regulates stomatal closure in Arabidopsis thaliana. J. Pineal Res. 2018, 65, e12500. [CrossRef] [PubMed]

78. Cui, G.; Sun, F.; Gao, X.; Xie, K.; Zhang, C.; Liu, S.; Xi, Y. Proteomic analysis of melatonin-mediated osmotic tolerance by improving energy metabolism and autophagy in wheat (Triticum aestivum L.). Planta 2018, 248, 69-87. [CrossRef]

79. Arnao, M.B.; Hernandez-Ruiz, J. Melatonin and its relationship to plant hormones. Ann. Bot. 2018, 121, 195-207. [CrossRef]

80. Zhou, L.; Zhou, J.; Xiong, Y.; Liu, C.; Wang, J.; Wang, G.; Cai, Y. Overexpression of a maize plasma membrane intrinsic protein ZmPIP1;1 confers drought and salt tolerance in Arabidopsis. PLoS ONE 2018, 13, e0198639. [CrossRef]

81. Wang, L.; Feng, C.; Zheng, X.; Guo, Y.; Zhou, F.; Shan, D.; Liu, X.; Kong, J. Plant mitochondria synthesize melatonin and enhance the tolerance of plants to drought stress. J. Pineal Res. 2017, 63, e12429. [CrossRef]

82. Burgess, P.; Huang, B. Mechanisms of Hormone Regulation for Drought Tolerance in Plants. In Drought Stress Tolerance in Plants, Vol 1: Physiology and Biochemistry; Hossain, M.A., Wani, S.H., Bhattacharjee, S., Burritt, D.J., Tran, L.-S.P., Eds.; Springer International Publishing: Cham, Swizerland, 2016; pp. 45-75.

83. Behnam, B.; Iuchi, S.; Fujita, M.; Fujita, Y.; Takasaki, H.; Osakabe, Y.; Yamaguchi-Shinozaki, K.; Kobayashi, M.; Shinozaki, K. Characterization of the promoter region of an Arabidopsis gene for 9-cis-epoxycarotenoid dioxygenase involved in dehydration-inducible transcription. DNA Res. 2013, 20, 315-324. [CrossRef] 
84. Kudoyarova, G.R.; Vysotskaya, L.B.; Cherkozyanova, A.; Dodd, C. Effect of partial rootzone drying on the concentration of zeatin-type cytokinins in tomato (Solanum lycopersicum L.) xylem sap and leaves. J. Exp. Bot. 2007, 58, 161-168. [CrossRef] [PubMed]

85. Choi, J.; Hwang, I. Cytokinin: Perception, signal transduction, and role in plant growth and development. J. Plant Biol. 2007, 50, 98-108. [CrossRef]

86. Lim, P.O.; Kim, H.J.; Nam, H.G. Leaf senescence. Annu. Rev. Plant Biol. 2007, 58, 115-136. [CrossRef] [PubMed]

87. Xu, Y.; Burgess, P.; Huang, B. Transcriptional regulation of hormone-synthesis and signaling pathways by overexpressing cytokinin-synthesis contributes to improved drought tolerance in creeping bentgrass. Physiol. Plant. 2017, 161, 235-256. [CrossRef] [PubMed]

88. Arnao, M.B.; Hernández-Ruiz, J. Protective effect of melatonin against chlorophyll degradation during the senescence of barley leaves. J. Pineal Res. 2009, 46, 58-63. [CrossRef] [PubMed]

89. Tanveer, M.; Shahzad, B.; Sharma, A.; Khan, E.A. 24-Epibrassinolide application in plants: An implication for improving drought stress tolerance in plants. Plant Physiol. Biochem. 2019, 135, 295-303. [CrossRef]

90. Hwang, O.J.; Back, K. Melatonin is involved in skotomorphogenesis by regulating brassinosteroid biosynthesis in rice plants. J. Pineal Res. 2018, 65, e12495. [CrossRef]

91. Xia, X.-J.; Gao, C.-J.; Song, L.-X.; Zhou, Y.-H.; Shi, K.A.I.; Yu, J.-Q. Role of $\mathrm{H}_{2} \mathrm{O}_{2}$ dynamics in brassinosteroid-induced stomatal closure and opening in Solanum lycopersicum. Plant Cell Environ. 2014, 37, 2036-2050. [CrossRef]

92. Bhargava, S.; Sawant, K.; Tuberosa, R. Drought stress adaptation: Metabolic adjustment and regulation of gene expression. Plant Breed. 2013, 132, 21-32. [CrossRef]

93. Anjum, S.A.; Wang, L.; Farooq, M.; Khan, I.; Xue, L. Methyl Jasmonate-Induced Alteration in Lipid Peroxidation, Antioxidative Defence System and Yield in Soybean Under Drought. J. Agron. Crop Sci. 2011, 197, 296-301. [CrossRef]

94. Shan, C.; Zhou, Y.; Liu, M. Nitric oxide participates in the regulation of the ascorbate-glutathione cycle by exogenous jasmonic acid in the leaves of wheat seedlings under drought stress. Protoplasma 2015, 252, 1397-1405. [CrossRef] [PubMed]

95. Anjum, S.A.; Tanveer, M.; Hussain, S.; Tung, S.A.; Samad, R.A.; Wang, L.; Khan, I.; Rehman, N.u.; Shah, A.N.; Shahzad, B. Exogenously applied methyl jasmonate improves the drought tolerance in wheat imposed at early and late developmental stages. Acta Physiol. Plant 2015, 38, 25. [CrossRef]

96. Wasternack, C. Jasmonates: An update on biosynthesis, signal transduction and action in plant stress response, growth and development. Ann. Bot. 2007, 100, 681-697. [CrossRef] [PubMed]

97. Murata, Y.; Mori, I.C. Stomatal regulation of plant water status. In Plant Abiotic Stress; Jenks, M.A., Hasegawa, P.M., Eds.; Wiley: New York, NY, USA, 2014; pp. 47-67.

98. Balbi, V.; Devoto, A. Jasmonate signalling network in Arabidopsis thaliana: Crucial regulatory nodes and new physiological scenarios. New Phytol. 2007, 177, 301-318. [CrossRef] [PubMed]

99. Goh, C.-H.; Lee, D.J.; Bae, H.-J. Gibberellic acid of Arabidopsis regulates the abscisic acid-induced inhibition of stomatal opening in response to light. Plant Sci. 2009, 176, 136-142. [CrossRef]

100. Teszlák, P.; Kocsis, M.; Gaál, K.; Nikfardjam, M.P. Regulatory effects of exogenous gibberellic acid (GA3) on water relations and $\mathrm{CO}_{2}$ assimilation among grapevine (Vitis vinifera L.) cultivars. Sci. Hortic. 2013, 159, 41-51. [CrossRef]

101. Kang, S.M.; Radhakrishnan, R.; Khan, A.L.; Kim, M.J.; Park, J.M.; Kim, B.R.; Shin, D.H.; Lee, I.J. Gibberellin secreting rhizobacterium, Pseudomonas putida H-2-3 modulates the hormonal and stress physiology of soybean to improve the plant growth under saline and drought conditions. Plant Physiol. Biochem. 2014, 84, 115-124. [CrossRef]

102. Li, Z.; Lu, G.Y.; Zhang, X.K.; Zou, C.S.; Cheng, Y.; Zheng, P.Y. Improving drought tolerance of germinating seeds by exogenous application of gibberellic acid (GA3) in rapeseed (Brassica napus L.). Seed Sci. Technol. 2010, 38, 432-440. [CrossRef]

103. Krugman, T.; Peleg, Z.; Quansah, L.; Chague, V.; Korol, A.B.; Nevo, E.; Saranga, Y.; Fait, A.; Chalhoub, B.; Fahima, T. Alteration in expression of hormone-related genes in wild emmer wheat roots associated with drought adaptation mechanisms. Funct. Integr. Genom. 2011, 11, 565-583. [CrossRef] 
104. Wang, L.; Zhao, Y.; Reiter, R.J.; He, C.; Liu, G.; Lei, Q.; Zuo, B.; Zheng, X.D.; Li, Q.; Kong, J. Changes in melatonin levels in transgenic 'Micro-Tom' tomato overexpressing ovine AANAT and ovine HIOMT genes. J. Pineal Res. 2014, 56, 134-142. [CrossRef]

105. Zuo, B.; Zheng, X.; He, P.; Wang, L.; Lei, Q.; Feng, C.; Zhou, J.; Li, Q.; Han, Z.; Kong, J. Overexpression of MzASMT improves melatonin production and enhances drought tolerance in transgenic Arabidopsis thaliana plants. J. Pineal Res. 2014, 57, 408-417. [CrossRef] [PubMed]

106. Pelagio-Flores, R.; Muñoz-Parra, E.; Ortiz-Castro, R.; López-Bucio, J. Melatonin regulates Arabidopsis root system architecture likely acting independently of auxin signaling. J. Pineal Res. 2012, 53, 279-288. [CrossRef] [PubMed]

107. Arnao, M.B.; Hernández-Ruiz, J. Melatonin and reactive oxygen and nitrogen species: A model for the plant redox network. Melatonin Res. 2019, 2, 152-168. [CrossRef]

108. Arnao, M.B.; Hernández-Ruiz, J. Is Phytomelatonin a New Plant Hormone? Agronomy 2020, 10, 95. [CrossRef]

109. Bhuyan, M.H.M.B.; Hasanuzzaman, M.; Parvin, K.; Mohsin, S.M.; Al Mahmud, J.; Nahar, K.; Fujita, M. Nitric oxide and hydrogen sulfide: Two intimate collaborators regulating plant defense against abiotic stress. Plant Growth Regul. 2020, 90, 409-424. [CrossRef]

110. Zhu, Y.; Gao, H.; Lu, M.; Hao, C.; Pu, Z.; Guo, M.; Hou, D.; Chen, L.Y.; Huang, X. Melatonin-Nitric Oxide Crosstalk and Their Roles in the Redox Network in Plants. Int. J. Mol. Sci. 2019, 20, 6200. [CrossRef]

111. Jin, Z.; Shen, J.; Qiao, Z.; Yang, G.; Wang, R.; Pei, Y. Hydrogen sulfide improves drought resistance in Arabidopsis thaliana. Biochem. Biophys. Res. Commun. 2011, 414, 481-486. [CrossRef]

112. Cheng, W.; Zhang, L.; Jiao, C.; Su, M.; Yang, T.; Zhou, L.; Peng, R.; Wang, R.; Wang, C. Hydrogen sulfide alleviates hypoxia-induced root tip death in Pisum sativum. Plant Physiol. Biochem. 2013, 70, 278-286. [CrossRef]

113. Mukherjee, S. Recent advancements in the mechanism of nitric oxide signaling associated with hydrogen sulfide and melatonin crosstalk during ethylene-induced fruit ripening in plants. Nitric Oxide 2019, 82, $25-34$. [CrossRef]

114. Shi, H.; Chen, Y.; Tan, D.-X.; Reiter, R.J.; Chan, Z.; He, C. Melatonin induces nitric oxide and the potential mechanisms relate to innate immunity against bacterial pathogen infection in Arabidopsis. J. Pineal Res. 2015, 59, 102-108. [CrossRef]

115. Mukherjee, S.; David, A.; Yadav, S.; Baluška, F.; Bhatla, S.C. Salt stress-induced seedling growth inhibition coincides with differential distribution of serotonin and melatonin in sunflower seedling roots and cotyledons. Physiol. Plant. 2014, 152, 714-728. [CrossRef] [PubMed]

116. Kaya, C.; Higgs, D.; Ashraf, M.; Alyemeni, M.N.; Ahmad, P. Integrative roles of nitric oxide and hydrogen sulfide in melatonin-induced tolerance of pepper (Capsicum annuum L.) plants to iron deficiency and salt stress alone or in combination. Physiol. Plant. 2020, 168, 256-277. [CrossRef] [PubMed]

117. Chen, H.; Feng, C.; Kong, J.; Wang, L.; Wang, N.; Zheng, X.; Zhou, Y.; Chan, D. Use of Product Containing Melatonin as Effective Component for Improving Waterlogging Stress Resistance in Plants. CN105076136-A, CN105076136-B, CN105076136-A, 25 November 2015. A01N-043/38 201612.

118. Zheng, X.; Zhou, J.; Tan, D.X.; Wang, N.; Wang, L.; Shan, D.; Kong, J. Melatonin Improves Waterlogging Tolerance of Malus baccata (Linn.) Borkh. Seedlings by maintaining aerobic respiration, photosynthesis and ROS Migration. Front. Plant Sci. 2017, 8, 483. [CrossRef] [PubMed]

119. Zhang, Q.; Liu, X.; Zhang, Z.; Liu, N.; Li, D.; Hu, L. Melatonin improved waterlogging tolerance in alfalfa (Medicago sativa) by reprogramming polyamine and ethylene metabolism. Front. Plant Sci. 2019, 10, 44. [CrossRef] [PubMed]

120. Arnao, M.B.; Hernández-Ruiz, J. Melatonin as a chemical substance or as phytomelatonin rich-extracts for use as plant protector and/or biostimulant in accordance with EC legislation. Agronomy 2019, 9, 570. [CrossRef]

121. Pérez-Llamas, F.; Hernández-Ruiz, J.; Cuesta, A.; Zamora, S.; Arnao, M.B. Development of a phytomelatonin-rich extract from cultured plants with excellent biochemical and functional properties as an alternative to synthetic melatonin. Antioxidants 2020, 9, 158. [CrossRef]

(C) 2020 by the authors. Licensee MDPI, Basel, Switzerland. This article is an open access article distributed under the terms and conditions of the Creative Commons Attribution (CC BY) license (http://creativecommons.org/licenses/by/4.0/). 